\title{
Hepatotoxicity Implies Chemical-Driven Liver Damage Induced By Certain Medicinal and Other Chemical Agents
}

\author{
Mohamad Sayyed Bakheet 1, Haredy Hassan Haredy 2, Ali Abdesalam 2, Hoda Khalifa Abd alhady sayed3 \\ 1Department of Biochemistry, Faculty of Medicine, Al-Azhar University, Assuit, Egypt, \\ 2Department of pharmacology, Faculty of Medicine, Al-Azhar University, Assuit, Egypt, \\ 3Department of physiology, Faculty of Medicine, Al-Azhar University, Assuit, Egypt.
}

\begin{abstract}
:
There are increasing evidences that free radicals and reactive oxygen species play a crucial role in the various steps that initiate and regulate the progression of liver diseases. Oxidative stress in hepato-toxicity resulting from increased generation of reactive oxygen species (ROS) and other reactive intermediates as well as by decreased efficiency of antioxidant defenses actively contributes to excessive tissue remodeling. Drug-induced nephropathy is reported to be the third most common cause of acute renal failure in hospitalized patients. Excess ROS production and depressed antioxidant defence mechanism are responsible for nephrotoxicity.So, pharmacological studies in this work were done to evaluate: presence of protective effects of an antioxidant Hesperedine on carbon tetrachlorideinduced hepatic toxicity and nephro-toxicity, to evaluate its effects on oxidants and antioxidants parameters and to evaluate its effect on kidney and liver functions and histo-pathological changes.Liver enzymes level AST and ALT : was increased significantly in rats treated with $\mathrm{CCl} 4$ but decreased significantly in rats treated with antioxidant HDN (100 mg/ kg/ day) and in rats treated with antioxidant HDN $(200 \mathrm{mg} / \mathrm{kg} / \mathrm{day})$. in comparison between antioxidant treated rats groups liver enzymes level was decreased significantly in rats treated with antioxidant HDN $(200 \mathrm{mg} / \mathrm{kg} / \mathrm{day})$ than in rats treated with antioxidant HDN (100 mg/ kg/ day) .Serum creatinine level: was increased insignificantly in rats treated with $\mathrm{CCl} 4$ but decreased insignificantly in rats treated with antioxidant HDN $(100 \mathrm{mg} / \mathrm{kg} / \mathrm{day})$ and in rats treated with antioxidant HDN (200 mg/ kg/ day). in comparison between antioxidant treated rats groups liver enzymes level was decreased insignificantly in rats treated with antioxidant HDN (200 mg/ $\mathrm{kg} /$ day) than in rats treated with antioxidant HDN (100 mg/ kg/ day). So, we recommend uses of antioxidant Hesperedine as it has a valuable role in improvement of liver functions and as a prophylactic of hepatic and renal tissues against toxicity achieved by free radicals.
\end{abstract}

\section{INTRODUCTION}

Hepato-toxicity Implies chemical-driven liver damage. Certain medicinal agents, when taken in overdoses and sometimes even when introduced within therapeutic ranges, may injure the organ. Other chemical agents, such as those used in laboratories and industries, natural chemicals (e.g., microcystins) and herbal remedies can also induce hepatotoxicity. Chemicals that cause liver injury are called hepatotoxins. Chemicals often cause subclinical injury to liver which manifests only as abnormal liver enzyme tests. Drug-induced liver injury is responsible for 5\% of all hospital admissions and $50 \%$ of all acute liver failures. More than $75 \%$ of cases of idiosyncratic drug reactions result in liver transplantation or death (Ostapowicz et al., 2002; McNally and Peter, 2006).

Mitochondria are prominent targets for the hepato-toxicity of many drugs. Dysfunction of these vital cell organelles results in impairment of energy metabolism and an intracellular oxidant stress with excessive formation of reactive oxygen species and peroxy-nitrite. Induction of cytochrome P450 isoenzymes such as CYP2E1 also promotes oxidant stress and cell injury, once hepatocellular function is impaired, accumulation of bile acids causes additional stress and cytotoxicity. Cell injury, gut-derived endotoxin or a combination of both also activate Kupffer cells and recruit neutrophils into the liver. Although responsible for removal of cell debris and part of the host-defense system, under certain circumstances these inflammatory cells initiate additional liver injury (Jaeschke et al., 2002).

Drug-induced liver diseases mimic all forms of acute and chronic hepatobiliary diseases. However, the predominant clinical presentation resembles acute icteric hepatitis or cholestatic liver disease. The former is the more serious and often has a 10\% mortality rate, regardless of the causative drug, (Zimmerman, 1999; and Kaplowitz, 2002).

Acute icteric hepatitis is accompanied by markedly elevated serum transaminase levels and a minimal increase in the level of alkaline phosphatase. Coagulopathy and encephalopathy are present in more severe cases. Cholestatic disease (which is also referred to as cholestatic hepatitis) is not usually life threatening; it presents with jaundice, 
pruritus, and marked increases in alkaline phosphatase levels, as well as mild increases in alanine aminotransferase (ALT) levels. Mixed injury patterns with intermediate to marked increases in ALT and alkaline phosphatase levels can resemble atypical hepatitis or granulomatus hepatitis, (Kaplowitz, 2002).

Biochemical markers (e.g. alanine transferase, alkaline phosphatase and bilirubin) are often used to indicate liver damage. Liver injury is defined as a rise in either (a) ALT level more than three times of upper limit of normal (ULN), (b) ALP level more than twice ULN, or (c) total bilirubin level more than twice ULN when associated with increased ALT or ALP, (Bénichou, 1990 and Mumoli et al., 2006).

Oxidative stress in hepatotoxicity, resulting from increased generation of reactive oxygen species (ROS) and other reactive intermediates as well as by decreased efficiency of antioxidant defenses, actively contributes to excessive tissue remodeling, (Ismail and Pinzani ,2009).

Indeed, oxidative stress, presumably by favoring mitochondrial permeability transition, is able to promote hepatocyte death (necrotic and/or apoptotic). In some of clinically relevant conditions, generation of ROS within hepatocytes may represent a consequence of an altered metabolic state (like in NAFLD and NASH) or of ethanol metabolism (as in ASH), with ROS being generated mainly by mitochondrial electron transport chain or through the involvement of selected cytochrome P450 isoforms like cytochrome P2E1 (CYP2E1), (Tilg and Hotamisligil ,2006).

Glutathione (GSH) is a critical cellular antioxidant. After GSH depletion with buthionine sulfoximine (BSO), the toxicity of ethanol, iron, arachidonic acid, and acetaminophen was strikingly enhanced, (Chen et al., 1997; Chen and Cederbaum, 1998; Sakurai and Cederbaum, 1998; Wu and Cederbaum, 1999).

Cytochrome P4502E1 (CYP2E1), the ethanol-inducible form, metabolizes and activates many toxicologically important substrates, including ethanol, carbon tetrachloride, acetaminophen, and N-nitrosodimethylamine, to more toxic products, (Guengerich et al. ,1990; Koop ,1992). CYP2E1- dependent ethanol metabolism produces oxidative stress through generation of reactive oxygen species (ROS), a possible mechanism by which ethanol is hepatotoxic, (Dianzani , 1985 and Bondy, 1992). Induction of cytochrome P4502E1 by ethanol is a central pathway by which ethanol generates oxidative stress, and in the intragastric model of ethanol feeding a prominent induction of CYP2E1 occurs along with significant alcohol liver injury, (Morimoto et al. ,1994; Nanji et al. , 1994).

Immunochemical studies indicate that the cellular site of covalent binding correlates with the toxicity, (Roberts et al., 1991 and Hart et al., 1995). Recent work shows that nitrated tyrosine occurs in hepatic centrilobular cells. These adducts colocalize in cells containing the acetaminophen-protein adducts, (Hinson et al., 2000). Peroxynitrite, a highly reactive nitrating and oxidizing species formed by the rapid reaction of nitric oxide (NO) and superoxide, produces nitrated tyrosine, (Pryor and Squadrito, 1995; Beckman, 1996).

Carbon tetrachloride is a colourless liquid, non flammable, and is heavier than air, (Etim et al., 2008). Consequently, it has been widely used as a fire extinguisher being useful for fighting fires near electrical equipment because it does not conduct electricity, (The World Book Encyclopedia, 1992). Carbon tetrachloride is very toxic and because of this, most of its uses in households and industries have been suspended, (Etim et al., 2008). Consequently, little is known about the early effects of this organic solvent in vivo, particularly on mitochondrial function. It has been shown recently in a murine model of liver fibrosis that chronic administration of $\mathrm{CCl} 4$ for 6 weeks led to mitochondrial DNA (mtDNA) alterations, reduced glutathione (GSH) depletion and decreased aconitase activity (Mitchell et al, 2009), overexpression of Bcl-2 reduced liver fibrosis for the first 3 weeks of treatment by protecting hepatocytes against mitochondrial damage, but subsequently failed to prevent fibrosis with the persistence of the aggression. CCl4 is activated by cytochrome P450 (CYP) 2E1, and very marginally by other CYPs (CYP2B and CYP3A), to form the trichloromethyl $(\mathrm{CCl} 3)$ free radical, which can react with oxygen to produce the trichloromethyl peroxy radical $(\mathrm{CCl} 3 \mathrm{OO})$. Both radicals are highly reactive species that may covalently bind to macromolecules to form nucleic acid, protein and lipid adducts. However, the evidence for such interactions with liver DNA in vivo is limited, (Recknagel et al., 1989 and Weber et al., 2003).

In this study, we used an in vivo model to explore the very early toxic events, particularly regarding mitochondria, occurring after $\mathrm{CCl} 4$ administration. Inhibition of $\mathrm{CCl} 4$ activation by the CYP2E1 inhibitor diethyldithiocarbamate (DDTC) and impairment of CCl4-induced lipid peroxidation by antioxidants allowed us to establish a direct link between lipid peroxidation and mitochondrial alterations. Antibiotics, commonly used aminoglycosides, are nephrotoxic agents. Their nephrotoxicity is mainly attributed to induction of OS and depletion of antioxidat enzyme activities in kidney. Inducible nitric oxide synthase, nuclear factor kappa-B, nitogen-activated protein kinase (iNOS/NFkB/p38MAPK respectively) pathway, OS taking place in this axis, is involved in gentamicin-induced 
nephrotoxicity, (Tugcu et al. ,2006 and Ozbek et al. ,2009). The protective effect of anti oxidants and reactive oxygen scavenger agents against gentamicin-induced nephrotoxicity. Antineoplastic agents are commonly used for the treatment of metastatic cancers. Some of these are nephrotoxic, (Ozbek et al., 2010 and Maniu et al., 2011).Excess ROS production and depressed antioxidant defence mechanism are responsible for nephrotoxicity. Cisplatin is the well-known and commonly used antineoplastic and nephrotoxic agent. Other nephrotoxic anticancer agents are carboplatin, methotrexate, doxorubicin, cyclosporine, and adriamycin. Immunosuppressant such as sirolimus and cyclosporine leads to nephrotoxicity via OS, (Giustarini et al., 2009).

In this era, analgesics, especially paracetamol and acetaminophen (APAP), and nonsteroidal anti-inflammatory drugs (NSAIDs) are widely used throught the world. Paracetamol and APAP are nephrotoxic drugs. Several in vitro and in vivo studies showed that analgesics nephrotoxicity is caused by increased ROS in kidney, (Zhao et al, 2011) showed the increased ROS, nitric oxide, and MDA levels, together with depleted glutathione (GSH) concentration in the kidney of rats. However, rhein, Chinese herb, can attenuate APAP-induced nephrotoxicity in a dose-dependent manner, (Zhao et al., 2011).Some studies showed a significant increase in MDA and decreases in GSHPx, CAT, and SOD activities in APAPtreated rat kidneys. These findings support the induction of OS in rat kidney by APAP. Significant beneficial changes were noted in serum and tissue OS indicators in rats treated with strong antioxidant pineal hormone melatonin and curcumin, ( Ilbey et al. ,2009 ; Cekmen et al. ,2009), ,reported increased OS and TNFalpha production in rat tissues, (Ghosh et al. 2010), reported that diclofenac (NSAID) leads to nephrotoxicity by increasing intrarenal ROS in rat kidney, and antioxidant, Nacetylcysteine, prevents kidney damage, (Efrati et al. ,2007). GSH is able to regenerate the most important antioxidants, Vitamins C and E, back to their active forms; it can reduce tocopherol radical of Vitamin E directly, or indirectly, via reduction of semidehydroascorbate to ascorbate. The capacity of glutathione to regenerate the most important antioxidants is linked with the redox state of the glutathione disulphide-glutathione couple (GSSG/2GSH), (Pastore et al. , 2003). Hesperidin is a flavanone glycoside named after the term 'Hesperidium', referring to citrus fruits which are the main source of hesperidin. Hesperidin and its aglycone are common dietary flavonoids due to being large compounds of citrus fruits (alongside naringenin) and especially the peels and pericarp, (Kanes et al, 1993).

There are inhibitory effects of hesperitin on two intestinal transporters, the OATP2B1 (Organic Acid Transporting Polypeptide 2B1) transporter and MRP2 (Multidrug Resistance Protein 2). OATP2B1 appears to be acutely inhibited with supplementation of hesperidin, whereas low doses of hesperidin over a few weeks appear to downregulate the MRP2 transporter .It is notable to know that the OATPs play a fundamental role in the transport of drugs across the cell membrane, particularly in the liver and kidney. In the liver, OATPs are expressed on the basolateral membrane of hepatocytes, transporting compounds into the hepatocyte for biotransformation (Price et al, 2006).

A $0.079 \%$ hesperidin suspension given to rats for eight weeks is able to increase the overall exposure (147\%) and peak concentration (138\%) to the drug pravastatin, (Shirasaka et al ., 2013) which is thought to be due to inhibition of the transport protein known as Multi-drug Resistance Protein 2 (MRP2) that mediate pravastatin efflux into the intestines after absorption, (Tamai , 2012). There appear to be antioxidant effects in the brain where hesperidin reduces the increase in lipid peroxidation during cognitive damange, but this appears to be indirect through nitric oxide signalling (inhibition) rather than a direct antioxidant effect, (Olivenza et al. , 2000; McEwen, 2001; Alexaki et al., 2004 and Takeda et al., 2008). Damage of DNA is reduced by hesperidin (Sahu et al. ,2013).Hesperidin intake in diabetic rats appears to significantly but not fully reduce levels of the (vascular endothelial growth factors )VEGF and PKC $\beta$ (Protein kinase $c \beta$ ), and it is thought that the reduction in signalling (from VEGF towards PKC $\beta$ ) causes a protective effect on the retinal membrane and reduces the progression of diabetic retinopathy, (Donnelly et. al , 2004 ; Liu et al. , 2008 ; Wang et al. , 2010 and Kumar et al. , 2012).

\section{MATERIALS AND METHODS}

This study was conducted on Thirty two male albino rats. Animals were obtained from the animal house of faculty of medicine, Al-Azhar University. Their weight ranged between 160-200 grams each at the beginning of the experiment. Rats were housed in four groups with 8 rats each in clean capacious macrolane cages under standard laboratory conditions, including good aerated room with suitable temperature $\left(25 \pm 5^{\circ} \mathrm{C}\right)$, maintained at good light, standard rodent food and water were available.

$\mathrm{CCL}_{4}$ : El-Naser Pharmaceuticals chemical company, Egypt

Hesperidine (HDN): Sigma, Aldrich.

-Saline, El-Naser Pharmaceuticals chemical company, Egypt. 
- Phosphate buffered saline, Hi-media- Lab. Pvt. Inc., USA.

-SOD kit: Biochemical Enterprise, Italy

-Malon-Di-Aldehyde: Biochemical Enterprise, Italy

-Glutathione reduced determination kit: Biochemical Enterprise, Italy

- ALT and AST determination kits: Centronic_Gmbh, Germany.

-Serum Creatinine determination kits: Diamond., USA.

In the present study, the animals were divided into the following groups. Each group consisted of 8 rats:

Group I : These animals received a vehicle for HDN (i.e. CarboxyMethylCellulose) by oral route for eight days and on 8 th day, they were administered the subcutaneous injection of olive oil ).Tirkey(2005,

Group II: These animals received vehicle for 10 days and were challenged with CCl4 $2 \mathrm{ml} / \mathrm{kg} / \mathrm{s.c}$. (40\% v/v in olive oil) on 8th day (Mandal and Sinha, 2002)

Group III: These rats received only HDN 100 mg/kg/p.o. daily for 10 days CCl4+ HDN (100): Rats received HDN continuously for 8 days. On eight day just after HDN treatment they received CCl4 2ml/kg/s.c in olive oil. HDN was further continued for 2 more days. (Tirkey, 2005)

Group IV: These rats received only HDN 200 mg/kg/p.o. daily for 10 days CCl4+ HDN (200): Rats received HDN continuously for 8 days. On eight day just after HDN treatment they received CCl4 2ml/kg/s.c in olive oil. HDN was further continued for 2 more days.( ( Tirkey, 2005)

Forty-eight hours after the last $\mathrm{CCl} 4$ injection, rats were sacrificed and blood samples were collected, centrifuged and the serum from each animal was kept in epindorff tubes in the deep freezer at $\left(-20^{\circ} \mathrm{C}\right)$ until analyzed for liver functions.

After animals were sacrificed livers were immediately excised, rinsed from blood in ice cold saline, blotted dry by filter papers. Small piece of each liver was fixed in 10\% phosphate-buffered formalin for histological examination. About $0.5 \mathrm{gm}$ of each liver was homogenized by ultra sonic homogenizer in $5 \mathrm{ml}$ ice-cold phosphate bufferd saline (PBS) to obtain ultimately10\% (w/v) whole liver homogenate (Ezz et al., 2011 ;Fahmy and Hamdi, 2011). The homogenate was centrifuged at $3000 \mathrm{rpm}$ for $15 \mathrm{~min}$ and the resultant supernatant was stored at $-20^{\circ} \mathrm{C}$ until used for determination of reduced glutathione (GSH), malondialdhyde (MDA), superoxide dismutase (SOD) and hydroxyproline concentration.

Determination of liver function:

Determination of alanine aminotransferase (ALT) (IU/L): (Thomas , 1998)

Determination of aspartate aminotransferase (AST) (IU/L): (Thomas , 1998).

Determination of kidney function:

Determination of Serum Creatinine (mg/dL): (Murray, 1984)

Determination of hepatic reduced glutathione $\mathrm{mg} / \mathrm{g}$ tissue: (Beutler, 1963).

Determination of hepatic superoxide dismutase U/g tissue: Nishikimi et al (1972 ,.

Determination of hepatic lipid peroxide (malondialdehyde) nmol/g tissue: (Satoh, 1978)

\section{RESULTS}

Table1. Augmented results of all biochemical parameters in all groups.

\begin{tabular}{|l|l|l|l|l|l|}
\hline & Groups & $\begin{array}{l}\text { GROUP I } \\
\text { CONTROL-VE } \\
\text { NO CCL4 } \\
\text { NO HDN } \\
8 \text { rats }\end{array}$ & $\begin{array}{l}\text { GROUP II } \\
\text { CONTROL+VE } \\
\text { CCL4 } \\
\text { NO HDN } \\
8 \text { rats }\end{array}$ & $\begin{array}{l}\text { GROUP III } \\
\text { HESPEREDINE } \\
(100 \mathrm{mg} / \mathrm{kg})\end{array}$ & $\begin{array}{l}\text { GROUP IV } \\
\text { HESPEREDINE } \\
(200 \mathrm{mg} / \mathrm{kg})\end{array}$ \\
$\begin{array}{l}\text { Parameters } \\
\text { Melondialdehyde } \\
\text { (mg/tissue) }\end{array}$ & $\begin{array}{l}\text { Mean } \\
\pm \text { S.E }\end{array}$ & $\begin{array}{l}49.013 \pm 1.03 \\
82.763 \pm 0.91\end{array}$ & $81.625 \pm 0.68$ & $80.2 \pm 0.38$ \\
\hline
\end{tabular}


American Research Journal of Pharmacy, Volume 1, Issue 2, 2015

\begin{tabular}{|l|l|l|l|l|l|}
\hline $\begin{array}{l}\text { Glutathione } \\
\text { (mg/tissue) }\end{array}$ & $\begin{array}{l}\text { Mean } \\
\pm \text { S.E }\end{array}$ & $5.088 \pm 0.06$ & $2.88 \pm 0.048$ & $3.09 \pm 0.067$ & $5.025 \pm 0.072$ \\
\hline $\begin{array}{l}\text { Superoxide } \\
\text { dismutase } \\
(\mathrm{mg} / \text { tissue })\end{array}$ & $\begin{array}{l}\text { Mean } \\
\pm \text { S.E }\end{array}$ & $107.888 \pm 0.56$ & $89.688 \pm 0.45$ & $90.863 \pm 0.26$ & $107.013 \pm 1.77$ \\
\hline $\begin{array}{l}\text { (AST) } \\
\text { aspartate } \\
\text { aminotransferase } \\
\text { (IU/L) }\end{array}$ & $\begin{array}{l}\text { Mean } \\
\pm \text { S.E }\end{array}$ & $48.725 \pm 0.47$ & $163.875 \pm 2.99$ & $111.375 \pm 1.78$ & $71.375 \pm 1.71$ \\
\hline $\begin{array}{l}\text { (ALT) } \\
\text { alanine } \\
\text { aminotransferase } \\
\text { (IU/L) }\end{array}$ & $\begin{array}{l}\text { Mean } \\
\pm \text { S.E }\end{array}$ & $38.5 \pm 0.76$ & $87.875 \pm 1.46$ & $57.375 \pm 1.28$ & $46.5 \pm 0.94$ \\
\hline $\begin{array}{l}\text { Serum Creatinine } \\
\text { dL) }\end{array}$ & $\begin{array}{l}\text { Mean } \\
\pm \text { S.E }\end{array}$ & $0.864 \pm 0.058$ & $1.063 \pm 0.082$ & $1.024 \pm 0.039$ & $0.936 \pm 0.09$ \\
\hline
\end{tabular}

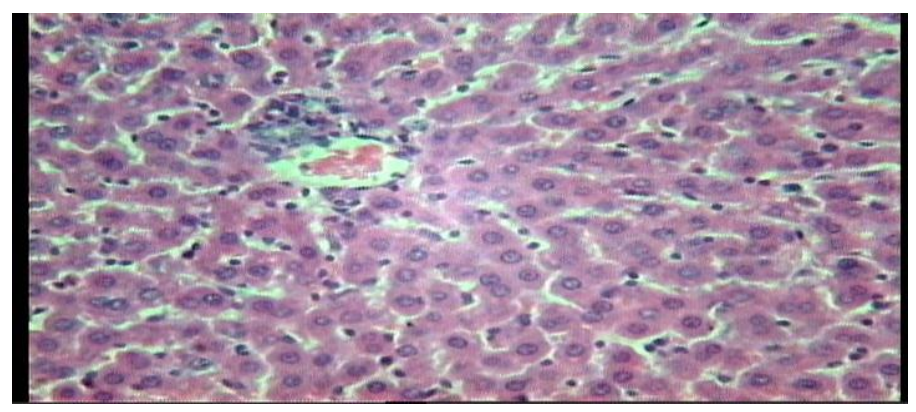

Fig1. Liver tissue of the (Group I control -ve) which were fed 5\% carboxymethyl cellulose (as a vehicle) only for 10 days and were injected by olive oil S.C in the 8th day

-Normal liver tissue

-Normal architecture -normal rows

-No inflammatory cell infilterate

-Normal cellular appearance

-Normal apparent nuclei

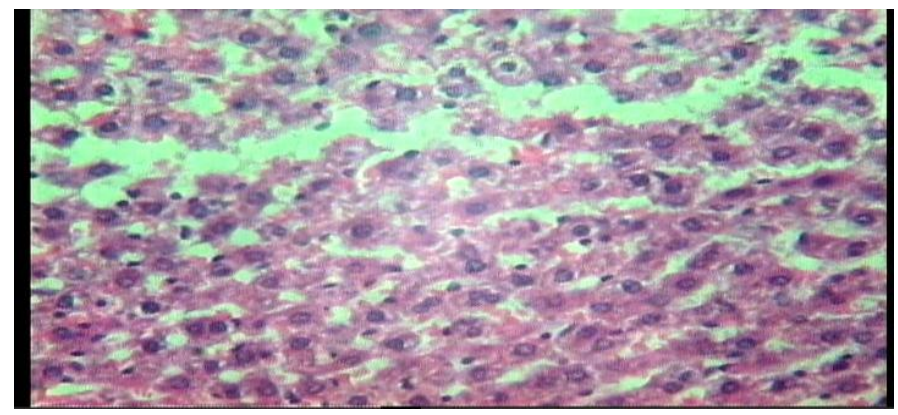

Figure2. Liver tissue of the (Group II control +ve) Which were fed 5\% carboxymethyl cellulose (as a vehicle) only for 10 days and were injected by $\mathrm{CCl}_{4}$ in olive oil $(2 \mathrm{ml} / \mathrm{kg})$ S.C in the 8 th day

-Extensive damage.

-Very sever vaculation

-Inflammatory cell infilteration

-Disruption of the lattice nature of hepatocytes and damaged hepatocyte cell membrane

-Irregular architecture (damaged sinusoids, rows and disintegrated central vein)

-Degenerated nuclei 


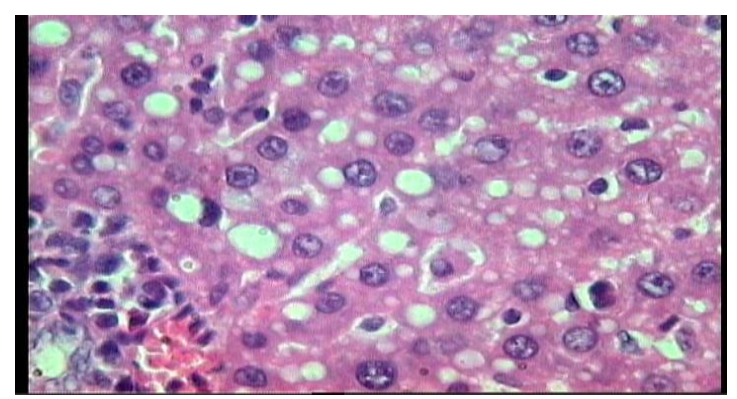

Fig3. Liver tissue of the (Group III treated with Hesperidine (HDN) as $100 \mathrm{mg} / \mathrm{kg}$ in the vehicle for 10 days and were injected by CCl4 in olive oil $(2 \mathrm{ml} / \mathrm{kg})$ S.C in the 8 th day .

-Presence of vaculation but less than control positive group.

-More eosinophis infiltration than control positive group.

-Better viability and less damage than control positive group.

-Nuclei are healthier than control positive group.

- Less disruption of the lattice nature of hepatocytes and less damaged hepatocyte cell membran

- More regular architecture and rows than control positive.

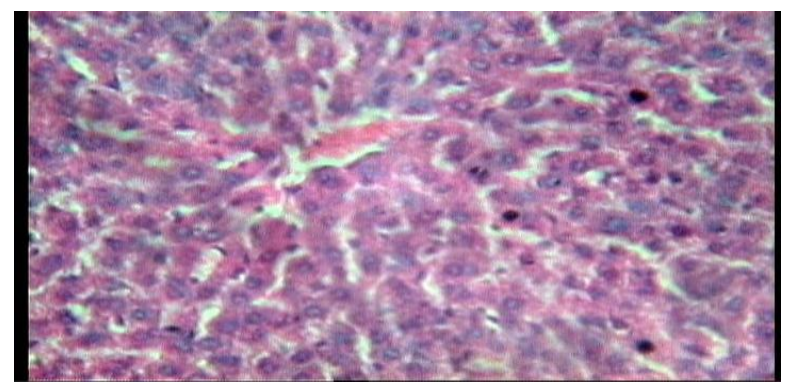

Fig4. Liver tissue of the (Group IV treated with Hesperidine (HDN) as 200mg/kg in the vehicle for 10 days and were injected by $\mathrm{CCl}_{4}$ in olive oil $(2 \mathrm{ml} / \mathrm{kg})$ S.C in the 8 th day .

-Faded vaculation (very mild)

-Architecture and rows are so close to normal.

-Normal viability

-Less infiltration by the inflammatory cells than treated groups by (HDN100)

-Normal nuclei and cell membranes

-Normal central vein and sinusoids.

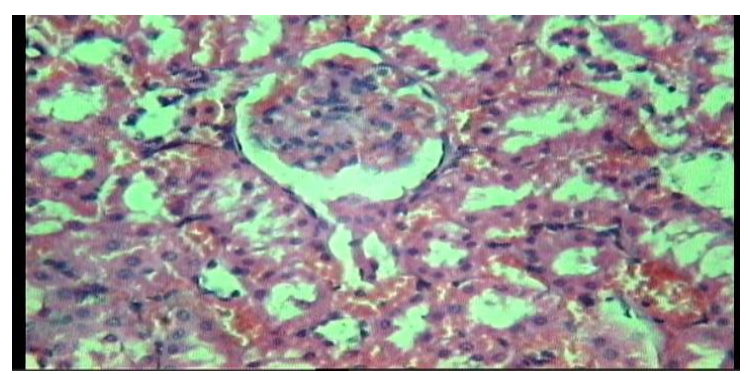

Fig5. Kidney tissue of the (Group I control -ve) which was fed 5\% carboxymethyl cellulose (as a vehicle) only for 10 days and was injected by olive oil S.C in the 8th day

-Normal glomeruli and tuft of capillaries, intact Bowman capsule

-Normal tubular apearence

-Normal vasculature 
-Normal viability

-No inflammatory cells infiltration

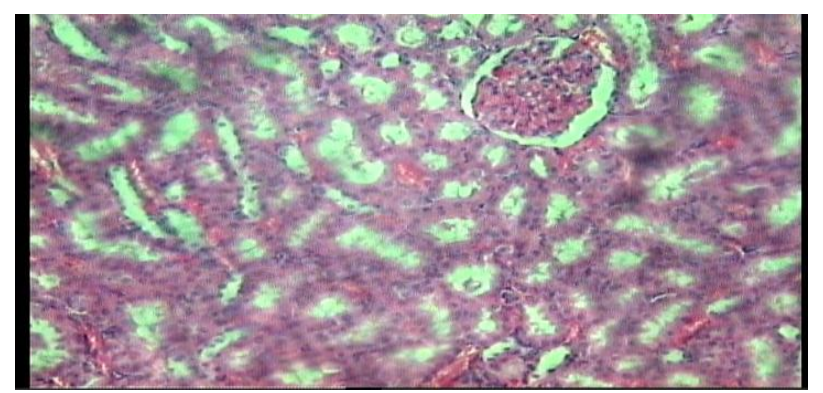

Fi6. Kidney tissue of the (Group II control $+v e$ ) which were fed 5\% carboxymethyl cellulose (as a vehicle) only for 10 days and were injected by $\mathrm{CCl}_{4}$ in olive oil $(2 \mathrm{ml} / \mathrm{kg}) \mathrm{S}$.C in the 8 th day

-Marked vaculation (extensive damage)

-Inflammatory cell infilteration (glomerular mainly)

-Disruption of the lattice nature of the cells and damaged cell membranes

-Damage is tubular more than glomerular.With slight obliteration of the tubules

-Degenerated nuclei.

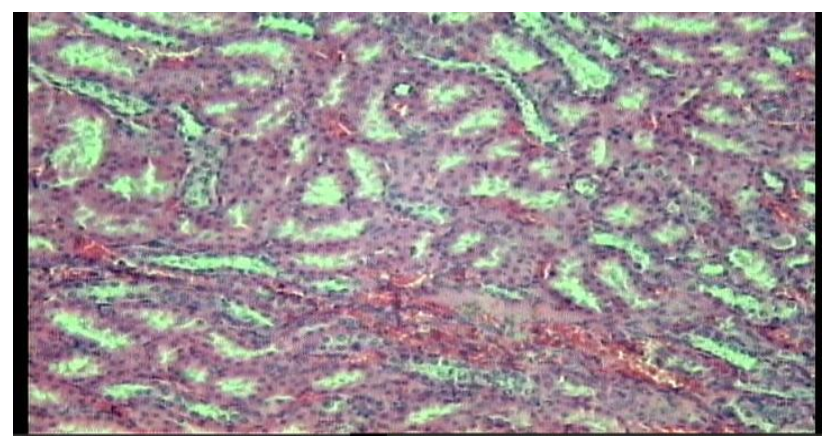

Fig7. Kidney tissue of the (Group III_treated with Hesperedine (HDN) as $100 \mathrm{mg} / \mathrm{kg}$ in the vehicle for 10 days and were injected by $\mathrm{CCl}_{4}$ in olive oil $(2 \mathrm{ml} / \mathrm{kg}) \mathrm{S}$.C in the 8 th day.

-Less vaculation of the tubules than control positive group.

-Less Inflammatory cell infilteration

-More viable cells than control positive group.

-Tubules appear to be more regular than control positive group.

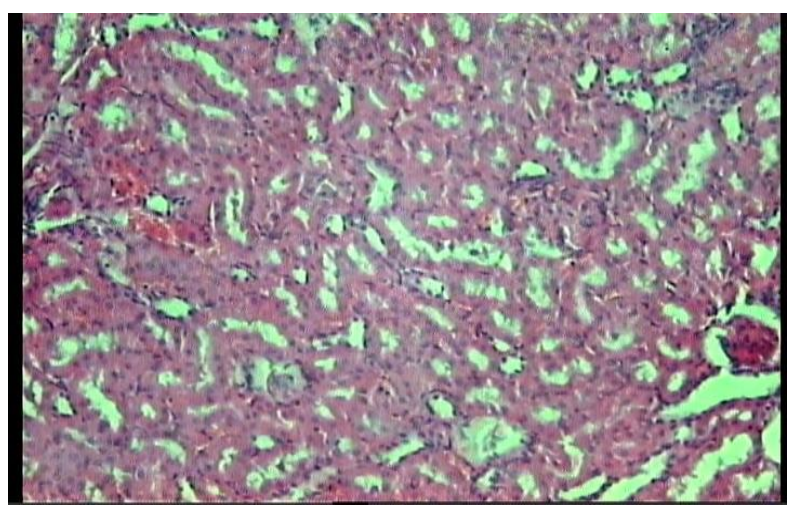

Fig8. Kidney tissue of the (Group IV treated with Hesperedine (HDN) as 200mg/kg in the vehicle for 10 days and were injected by CCl4 in olive oil $(2 \mathrm{ml} / \mathrm{kg})$ S.C in the 8 th day . 
-less vaculation in the tubules than in group III (HDN100)

-More viability of the cells than in group III (HDN100).

-More regular tubules than in group III (HDN100).

-Intact Bowman capsule

-It is so close to normal group

\section{DISCUSSION}

In the present study, induction of acute hepatic toxicity and nephrotoxicity in Wistar male albino rats was done by s.c injection of CCl4 $2 \mathrm{ml} / \mathrm{kg} / \mathrm{s} . c$. (40\% v/v in olive oil)for a single dose of which is a well characterized model for acute hepatic toxicity and nephrotoxicity has been extensively performed and revealed microscopically in the liver as extensive damage, very severe vaculation, inflammatory cells infilteration, Irregular architecture (damaged sinusoids, rows and disintegrated central vein) and degenerated nuclei and in the kidney as vaculation, degenerated nuclei , obliteration of the tubules, inflammatory cell infilteration and disruption of the lattice nature of the cells and damaged cell membranes. These results are in agreement with the results obtained by Al-Qarawi et al, 2004 who reported the hitopathological changes in acute hepatic toxicity, Montilla et al, 1990 who proved CCl4 hepatotoxicity by LD50 of CCl4, the modification of Nembutal-induced sleep, the action on bile flow, serum transaminase and hepatic fatty acids levels and a histopathological study of liver tissue. Kodama and Oguchi, 1990 and Prakash et al, 2008, have also obtained similar results to our study on the effect of CCl4 on hepatic and kidney architecture. Abdel Moneim and Mahmoud, 2013, who reported that CCl4 induces nephrotoxicity which can be detected by estimation of oxidation and antioxidation components plus histopathological changes. Khan et al, 2009, noticed glomerular degeneration, tubular brush border loss, tubular dilatation, necrosis of epithelium and interstitial oedema in CCl4 treated rats. The results of the present study are in disagreement with the results obtained by, Zimmerman et al ,1983 as they found an increased frequency of glomerulosclerosis ,tubulointerstitial alterations and reduced renal mass only on long-term $\mathrm{CCl} 4$ administration in rats. $\mathrm{CCl} 4$ not only initiates lipid peroxidation but also reduces tissue GSH and SOD activities, and this depletion may result from oxidative modification of these proteins, (Augustyniak et al., 2005). CCl4 intoxication can lead to alteration in gene expression and depletion of SOD and catalase levels in kidney and heart. Oxidative stress causes depletion of intracellular GSH, leading to serious consequences. CCl4-induced early signs of hepatotoxicity could be mediated through two different mechanisms involving or not lipid peroxidation. Lipid peroxidation triggered mtDNA degradation and mitochondrial dysfunction but not other CCl4-induced deleterious events such as hepatocyte swelling, abnormal expression of heme oxygenase $1(\mathrm{HO}-1)$ and heat shock protein (Hsp70), and reduction of CYP2E1 mRNA levels,(Szymonik-Lesiuk et al. ,2003) . Kidney tissue has great affinity for CCl4 because of the predominant presence of the cytochrome p450 in the cortex. Previous reports suggest that $\mathrm{CCl} 4$ generates free radicals with the implication of pathological environment by damaging the integrity of cell membranes, elevating thiobarbituric acid reactive substances (TBARS) level with subsequent necrosis and affecting physical parameters of kidney such as urinary and serum profile (Sahreen et al., 2011).

In the present study, $\mathrm{CCl} 4$ induces a severe hepatic damage as represented by markedly elevated levels of ALT and AST. These results are in agreement with the studies Alam et al, 2000 ; Mousa et al ,2004 and Prakash et al, 2008 who proved that administration of $\mathrm{CCl} 4$ causes hepatotoxicity detected by increased levels of ALT and AST.

Usually, the extent of hepatic damage is assessed by the increased level of cytoplasmic enzymes (ALT and AST), thus leads to leakage of large quantities of enzymes into the blood circulation. This was associated by massive centrilobular necrosis, ballooning degeneration and cellular infiltration of the liver, (Shankar et al., 2008).In response to hepatocellular injury initiated by the biotransformation of CCl4 to reactive radicals, "activated" Kupffer cells in liver respond by releasing increased amounts of active oxygen species and other bioactive agents, ( El-Sisi et al, 1993) these products include conjugated dienes, lipid hydroperoxides, malonaldehyde-like substances, and other short-chain hydrocarbons, (Tom et al ,1984).

Reduced glutathione (GSH) is a major endogenous antioxidant which counterbalances free radical mediated damage. It is well known that GSH is involved in the protection of normal cell structure and function by maintaining the redox homeostasis, quenching of free radicals and by participating in detoxification reactions, (Pushpakiran et al., 2004).

Superoxide dismutase (SOD) an enzyme that catalyzes the dismutation of superoxide (O2-) into oxygen and hydrogen peroxide. Thus, it is an important antioxidant defense in nearly all cells exposed to oxygen, (Shahid et al., 2012). 
The results of the present study showed that, subcutaneous injection of $\mathrm{CCl} 4$ lead to decreased hepatic reduced glutathione (GSH) level, superoxide dismutase (SOD) level and increased Malondialdehyde (MDA) level. These results are in agreement with the studies of Kang et al, 2001 who noticed that CCl4 causes decreased hepatic reduced glutathione (GSH) level, superoxide dismutase (SOD) level. Manjrekar et al, 2008 who noticed that CCl4 causes decreased hepatic reduced glutathione (GSH) level and increased Malondialdehyde (MDA) level. Siu-Po and Kam-Ming, 1996 who noticed that CCl4 causes decreased hepatic reduced glutathione (GSH) level.

Pereira-Filho et al, 2008 claimed that hepatic malondialdehyde (MDA) levels were also highly significantly increased in $\mathrm{CCl} 4$ treated group, showing an increased oxidative stress compared to control group. The increased MDA level suggests enhanced lipid peroxidation leading to tissue damage and failure of antioxidant defense mechanisms to prevent formation of excessive free radicals as described above and confirmed by, (George et al, 2002; Loki and Rajamohan, 2003 and Rajesh and Latha, 2004 and Kim et al 2010). The results of this present study are in disagreement with Stryjecka-Zimmer. et al , 2003 who claimed that change in antioxidant enzyme activities may be relevant to the ability of the liver and other investigated organs to cope with oxidative stress during CCl4 poisoning No statistically significant changes in SOD and glutathione peroxidase (GPX) activities were observed in the liver after $\mathrm{CCl} 4$ administration.

Oxidative stress in hepatotoxicity, resulting from increased generation of reactive oxygen species (ROS) and other reactive intermediates as well as by decreased efficiency of antioxidant defenses, actively contributes to excessive tissue remodeling (Ismail and Pinzani, 2009).ROS and other reactive mediators such as 4-hydroxynonenal (HNE) can be generated outside PMNLs, being released either by activated inflammatory cells or deriving from hepatocytes damaged by the specific etiological agent or conditions (Duffield et al., 2005). Indeed, oxidative stress, presumably by favoring mitochondrial permeability transition, is able to promote hepatocyte death (necrotic and/or apoptotic). In some of clinically relevant conditions, generation of ROS within hepatocytes may represent a consequence of an altered metabolic state (like in NAFLD and NASH), with ROS being generated mainly by mitochondrial electron transport chain or through the involvement of selected cytochrome P450 isoforms like cytochrome P2E1 (CYP2E1), (Tilg and Hotamisligil, 2006). Case control studies and various documented case reports increasingly establish that hydrocarbon solvents produce renal diseases in humans, (Ruprah et al, 1985).

To assess renal affection by detection of renal functions: Serum samples were assayed for serum creatinine, (Bhattacharya et al, 2005). The results of the present study showed that insignificant increase of Serum Creatinine in CCl4 intoxicated group.The results of the present study are in agreement with the studies of Zimmerman et al , 1983 who did not report any rise in kidney functions levels even after chronic treatment of CCl4 in nephrectomized rats , Ogawa et al ,1992 found an increased frequency of glomerulosclerosis and tubulointerstitial alterations in rats with reduced renal mass on $\mathrm{CCl} 4$ administration thereby indicating nephrotoxicity only on long-term $\mathrm{CCl} 4$ administration in rats. The results of the present study are in disagreement with Olagunjua et al, 2009 who noticed increase in kidney function in CCl4-induced nephrotoxicity and Stephen et al, 2007 who reported that the nephrotoxicity can be detected by kidney functions tests. Renal sources for ROS are activated macrophages, vascular cells, and various glomerular cells. ROS may affect cells of the host organism, especially at sites of inflammation in addition to playing a role in the defense system against other agents. This effect plays a role in a variety of renal diseases such as glomerulonephritis and tubulointerstitial nephritis which can contribute to proteinuria and other conditions (Ichikawa et al., 1994).

The presence of inflammation is well documented factor influencing the development of oxidative stress in dialysis patients (Samouilidou and Grapsa, 2003).However the pathology related with renal function failure that is stimulated by $\mathrm{CCl} 4$ remains controversial. As kidneys have an affinity against $\mathrm{CCl} 4$, and as they contain predominantly, cytochrome p450 in the cortex, it is very possible that $\mathrm{CCl} 4$ contributes a lot to nephrotoxicity, (Ogeturk et al., 2005).

The results of the present study showed that oral administration of hesperedine $(100 \mathrm{mg} / \mathrm{kg})$ and $(200 \mathrm{mg} / \mathrm{kg})$ significantly decrease the ALT and AST in CCl4-treated rat and in the group of the dose $200 \mathrm{mg} / \mathrm{kg}$ produces more decrease in ALT and AST. The results of the present study are in agreement with the study done by Ahmad et al, 2012 who proved that hesperedine ameliorates the hepatotoxicity-induced by acetaminophen, and this was detected by decrease in ALT and AST not only that but also he noticed that the acuity of toxicity is decreased gradually by increasing the dose of hesperedine similar to our results.

Balakrishan and Menon, 2007 reported that administration of hesperedine to nicotine treated rats at different doses decreases these enzymes significantly but in dose-dependent manner. Anandan and Ramaswamy, 2012 reported protective effects of hesperidin (HDN $100 \mathrm{mg} / \mathrm{kg}$ ) for 14 days against gentamicin (GEN $100 \mathrm{mg} / \mathrm{kg}$ ) induced 
hepatoxicity for 8 days detected by decrease in ALT and AST .Park et al, 2012 reported that protective effects of hesperidin+ Curdlan (HDN+CDN $100 \mathrm{mg} / \mathrm{kg}$ ) for 7 days against $\gamma$-radiation induced hepatoxicity .

AST and ALT are the aminotransferase in liver cells. They are cytoplasmic in nature, but upon liver injury large quantities of these enzymes enter into the circulatory system due to altered permeability of membrane, centrilobular necrosis, degeneration, and reduced performance status of the liver. So the elevated serum ALT and AST are the most sensitive biomarkers used in the diagnosis of liver diseases (Pari and Kumar, 2002 and Gao et al., 2012).

$\mathrm{CCl} 4$ induced a severe hepatic damage as represented by markedly elevated levels of ALTand AST coupled with a marked hepatic oxidative stress. (Tirkey. et al, 2005). Oxidative stress in hepatotoxicity, resulting from increased generation of reactive oxygen species (ROS) and other reactive intermediates as well as by decreased efficiency of antioxidant defenses, actively contributes to excessive tissue remodelling (Ismail and Pinzani, 2009). Hesperidin in combination with diosmin, shows a marked protective effect against inflammatory disorders, both in vivo and in vitro, possibly through a mechanism involving an inhibition of eicosanoid synthesis and/or antioxidant free radical scavenger activity (Jean and Bodinier, 1994).

The results of the present study showed that oral administration of Hesperedine $(100 \mathrm{mg} / \mathrm{kg})$ causes insignificant decrease in Malondialdehyde (MDA) and insignificant increased hepatic reduced glutathione (GSH) and superoxide dismutase (SOD) levels.

These results of the present study are in agreement with the study done by Tirkey et al, 2005 who proved that oral administration of Hesperedine $(100 \mathrm{mg} / \mathrm{kg}$ ) causes insignificant decrease in Malondialdehyde (MDA) and insignificant increased hepatic reduced glutathione (GSH) level and superoxide dismutase (SOD) level.

The results of the present study are in disagreement with the study done by Park et al, 2010 who observed protective effects of hesperidin+ Curdlan (HDN+CDN $100 \mathrm{mg} / \mathrm{kg}$ ) for 7 days against $\gamma$-radiation induced hepatoxicity, through significant decrease in Malondialdehyde (MDA) and significant increased hepatic reduced glutathione (GSH) level and superoxide dismutase (SOD) level .Anandan and Ramaswamy, 2012 observed protective effects of hesperidin but in gentamycine-induced hepatoxicity, this was detected by significant decrease in Malondialdehyde (MDA) and significant increased hepatic reduced glutathione (GSH) level and superoxide dismutase (SOD) level.

The present study showed that oral administration of Hesperedine $(200 \mathrm{mg} / \mathrm{kg})$ causes significant decrease in Malondialdehyde (MDA) and significant increase hepatic reduced glutathione (GSH) level and superoxide dismutase (SOD) level. These results are in agreement with the study done by (Xiao-min et al, 2011) who reported significant decrease in Malondialdehyde (MDA) and significant increased hepatic reduced glutathione (GSH) level and superoxide dismutase (SOD) level by studying the protective effect of Hesperidin on hepatotoxicity induced by cisplatin . Wei and Jun, 2010 posted that HDN had protective effects on CCl4-induced chemical liver injury. It was possibly related to removal of free radicals and inhibition of lipid peroxidation. $\mathrm{HDN}(250 \mathrm{and} 500 \mathrm{mg} / \mathrm{kg})$ could reduce the levels of MDA and significant increased hepatic superoxide dismutase (SOD) level. Wei and Jun, 2010 also observed certain cytokines as IL-1 and TNF are inhibited by HDN (250 and $500 \mathrm{mg} / \mathrm{kg}$ ) through decreasing mRNA expression. Xiao-min et al, 2011 reported that administration of hesperidin ( $300 \mathrm{mg} / \mathrm{kg}$ p.o.) for 7 consecutive days had a remarkable protective effect on hepatotoxicity induced by cisplatin $(5 \mathrm{mg} / \mathrm{kg}$, intraperitoneally for 5 consecutive days from the third day of hesperedine administration). The protective effect of hesperidin was possibly related to removal of free radicals and inhibition of lipid peroxidation produced by cisplatin intoxication. HDN $(300 \mathrm{mg} / \mathrm{kg})$ could reduce the levels of MDA, significant increased hepatic superoxide dismutase (SOD) level and significant increased GSH.

Shrivastava, 2011 noticed that administration of hesperidin (HDN) (100mg/kg p.o.), for 7 days had a remarkable protective effect on Cardiotoxicity induced by single intraperitoneal injection of cyclophosphamide CP $(200 \mathrm{mg} / \mathrm{kg}$ body weight). The protective effect of hesperidin was possibly related to removal of free radicals and inhibition of lipid peroxidation produced by cyclophosphamide intoxication .HDN $(100 \mathrm{mg} / \mathrm{kg})$ could reduce the levels of MDA, significant decreased LDH, CPK, ALT and AST. Also (Tirkey et al, 2005 and Pradeep et al, 2008) obtained similar results to our study on the effect of hesperedine on oxidants and antioxidants parameters.

Ko et al, 1995 reported that certain natural extracts containing antioxidants protect against the CCl4-induced increased lipid peroxide levels and impairment in hepatic GSH status.Hepatic malondialdehyde (MDA) levels were also highly significantly increased in CCl4 treated group, showing an increased oxidative stress compared to control group. The increased MDA level suggests enhanced lipid peroxidation leading to tissue damage and failure of 
antioxidant defense mechanisms to prevent formation of excessive free radicals as described by (Pereira-Filho et al, 2008) and confirmed by (Kim et al, 2010).

Glutathione is an important intracellular antioxidant that also plays a role in the detoxification and elimination of potential carcinogens and toxins. Studies in animals have found that glutathione synthesis and tissue glutathione levels are significantly lower in aged animals than in younger animals, leading to decreased ability of aged animals to respond to oxidative stress or toxin exposure (Hagen et al., 2000).

Superoxide dismutase (SOD) catalyzes the destruction of the $\mathrm{O} 2$ - free radical. $\left(2 \mathrm{O}^{2-}+2 \mathrm{H}^{+} \longrightarrow \mathrm{O}_{2}+\mathrm{H}_{2} \mathrm{O}_{2}\right.$ ).It protects oxygen-metabolizing cells against harmful effects of superoxide free-radicals (Petkau et al., 1975).

$\mathrm{CCl} 4$ challenge significantly decreased the levels of SOD and catalase in liver, by alteration in gene expression and depletion of SOD and catalase levels (Stryjecka-Zimmer et al, 2003). Antioxidants are agents that inhibit or neutralize potentially harmful elements known as free radicals (Zielinska el al., 2001; Galati and O'brien, 2004).

Flavonoids are naturally occurring polyphenolic compounds in plants that are thought to have positive effects on human health (Wahsha and Al-Jassabi, 2009). HDN administration ameliorates the increased level of lipid peroxidation after $\mathrm{CCl} 4$ treatment, able to show improvement in the levels of endogenous antioxidant enzymes SOD and Improvement of hepatic GSH levels in HDN-treated rats in comparison to CCl4 intoxicated rats, thereby this demonstrates the antioxidant effect of HDN (Tirkey et al, 2005). Flavonoids are known to operate via direct scavenging of Reactive Oxygen Species (ROS), chelation of redox active transition metal ions, inhibition of enzymes involved in ROS production, regeneration of endogenous antioxidants (Fitzgeorge et al., 1994 ; Zielinska et al.,2001). It was found that Hesperidin has an important antioxidant activity in humans, it enhances the integrity of the blood vessels and it is found in great quantity in citrus fruits (lemons and oranges) (Tripoli et al., 2007).

Hesperidin and Silymarin are polyphenolic compounds which play an important role as antioxidants; they can directly quench free radicals, inhibit the enzymes of oxygen reduction pathways and also prevent the sequestration of transient metal actions (Chatterjee et al., 1999; Berker et al., 2007). The radical scavenging power of flavonoids is thought to be related to their structure. Flavonoids in general, scavenge oxidizing radicals preferentially via their Bring catechol; in particular the ortho-dihydroxy structure in the B ring gives a higher stability during the formation of aroxyl radicals and participation in electron dislocation. The presence of the $3^{\prime}$ and 5' $\mathrm{OH}$ functions together give a maximum radical scavenging potential: this property is found in both Silymarin and Hesperidin, (Markham, 1982; Joshi et al., 2005; Andersen and Markham, 2006).

The results of the present study showed that oral administration of hesperedine $(100 \mathrm{mg} / \mathrm{kg})$ and $(200 \mathrm{mg} / \mathrm{kg})$ significantly improves hepatic architecture microscopically in dose-dependent manner as the group of hesperedine administration $(100 \mathrm{mg} / \mathrm{kg})$ shows slight improvement while the group of hesperedine administration $(200 \mathrm{mg} / \mathrm{kg})$ shows no difference with control normal group. This result is in agreement with the study done by (Balakrishan et al 2007) who observed that administration of hesperedine to nicotine treated rats at different doses improves hepatic architecture significantly in dose-dependent manner even in high doses ,he doesnot observe any morphological changes compared to normal. Ahmad et al, 2012 observed that Hesperidin alleviates acetaminophen induced toxicity in dose-dependent manner and in high doses he doesnot observe any morphological changes compared to normal.Also Bentli et al, 2013 obtained similar results to our study on the effect of hesperedine on hepatic architecture.

Our data showed that oral administration of hesperedine $(100 \mathrm{mg} / \mathrm{kg})$ and $(200 \mathrm{mg} / \mathrm{kg})$ significantly improves renal architecture microscopically in dose-dependent manner as the group of hesperedine administration $(100 \mathrm{mg} / \mathrm{kg})$ showed slight improvement while the group of hesperedine administration $(200 \mathrm{mg} / \mathrm{kg})$ showed no difference with control normal group. This result is in agreement with the histopathological study done by Anandan and Subramanian, 2012, who proved renal protective effect of hesperidin on gentamicin-induced acute nephrotoxicity. Balakrishan et al, 2006 administration of hesperedine to nicotine treated rats at different doses improves renal architecture significantly but in dose-dependent manner, and in high doses he doesnot observe any morphological changes compared to normal. Ahmad et al, 2012 observed that Hesperidin alleviates acetaminophen induced toxicity in dose-dependent manner and in high doses he doesnot observe any morphological changes compared to normal. Sahu et al, 2013 who reported that Hesperidin attenuates cisplatin-induced acute renal injury by decreasing oxidative stress, inflammation and DNA damage. 


\section{CONCLUSION}

The present study suggested that the antioxidant properties of Hesperedine might be the main factor responsible for its strong protective action on CCl4-induced hepatotoxicity and nephrotoxicity.

\section{REFERENCES}

[1] Abajo F.J., Montero D., Madurga M. and Garcia Rodriguez L.A.:"Acute and clinically relevant drug-induced liver injury: a population basedcase-control study". Br J Clin Pharmacol. 2004, 58: 71-80.

[2] Abdel Moneim A. E. and Mahmoud S.M. "The Protective Effect of Pomegranate (Punica granatum) Juice against Carbon Tetrachloride-Induced Oxidative Stress in Brain Tissue of Adult Male Albino Rats". Life Sci J 2013,10(1):151-158.

[3] Abdel-Raheem IT and Abdel-Ghany AA. :"Hesperidin alleviates doxorubicin-induced cardiotoxicity in rats". J Egypt Natl Canc Inst. 2009, 21(2):175-84.

[4] Abraham P, Wilfred G, Cathrine:"Oxidative damage to the lipids and proteins pf the lungs, testis and kidney of rats during carbon tetrachloride intoxication". Clin Chim Acta 1999,289:177-179.

[5] Agency for Toxic Substances and Disease Registry (ATSDR ), 2003

[6] Aguilaniu H., Gustafsson L., Rigoulet M., and Nystrom T.,: "Asymmetric inheritance of oxidatively damaged proteins during cytokinesis". Science, 2003 , 299:. 1751-1753.

[7] Ahmad ST, Arjumand W, Nafees S, Seth A, Ali N, Rashid S et al :"Hesperidin alleviates acetaminophen induced toxicity in Wistar rats by abrogation of oxidative stress, apoptosis and inflammation". Toxicol Lett. 2012 Jan 25;208(2):149-61.

[8] Alam K ,Al-Shabanah O A., Nagi M N, Al-RikabiA. C. and Al-Bekairi A.M :"Protective effect of aminoguanidine ,a nitric oxide synthase inhibitor ,against carbon tetracloride induced hepatotoxicity in mice" Life Scisaceq .2000, 66 : 265270.

[9] Alexaki VI, Charalampopoulos I, Kampa M, Vassalou H, Theodoropoulos P, Stathopoulos EN, et al.:"Estrogen exerts neuroprotective effects via membrane estrogen receptors and rapid Akt/NOS activation". FASEB J. 2004, 18(13):1594-6.

[10] Alonso J.J., Osorio J.M., Cabello F.G., Osa A.L., Leon L. and Garcia J.D.M. :"Atorvastatin induced cholestatic hepatitis in a young woman with systemic lupus erythematosus". Arch Intern Med. 1999, 159:1811-1812

[11] Al-Qarawi A A, Mousa HM, Ali BH, Abdel-Rahman H, El-Mougy SA:"Protective Effect of Extracts from Dates (Phoenix dactylifera L.) on Carbon Tetrachloride-Induced Hepatotoxicity in Rats" Intern J Appl Res Vet Med. 2004, Vol. 2, No. 3.

[12] Ameer B, Weintraub RA, Johnson JV, Yost RA and Rouseff RL. :"Flavanone absorption after naringin, hesperidin, and citrus administration". Clin Pharmacol Ther. 1996, 60(1):34-40.

[13] Anandan R. and Subramanian P. :"Effects of hesperidin on the levels of circulatory lipid peroxidation products and liver marker enzymes in gentamicin treated rats". J Pharm Res.2012, 5: 2114-2116.

[14] Andersen OM and Markham KR. :"Flavonoids: chemistry, biochemistry and applications". CRC Press, Boca Raton, 2006: $19-25$.

[15] Augustyniak, M., Babczynska, A., Migula, P., Wilczek, G.,Laszczyca, P., M. Augustyniaket al.:"Joint effects of dimethoate and heavy metals on metabolic responses in a grasshopper (Chorthippus brunneus) from a heavy metals pollution gradient". Comp.Biochem. Physiol. 2005, 141C: 412 - 419.

[16] Bailey DG, Dresser GK, Leake BF and Kim RB. " Naringin is a major and selective clinical inhibitor of organic aniontransporting polypeptide 1A2 (OATP1A2) in grapefruit juice". Clin Pharmacol Ther. $2007,81(4): 495-502$.

[17] Bakris G. L., Lass N., Gaber A. O., Jones J. D., and Burnett Jr J. C.: "Radiocontrast medium-induced declines in renal function: a role for oxygen free radicals". American Journal of Physiology 1990, vol. 258: F115-F120.

[18] Balaban R. S., Nemoto S., and Finkel T.. :"Mitochondria, oxidants, and aging". Cell 2005, 120: 483-495.

[19] Balakrishnan A and Menon VP :"Antioxidant properties of hesperidin in nicotine-induced lung toxicity". Fundam Clin Pharmacol. 2007 Oct;21(5):535-46.

[20] Barrett BJ and Parfrey PS. :"Clinical practice. Preventing nephropathy induced by contrast medium". N Engl J Med. 2006 , 354(4):379-386.

[21] Bashan N., Kovsan J., Kachko I., Ovadia H., and Rudich A.,: "Positive and negative regulation of insulin signaling by reactive oxygen and nitrogen species". Physiological Reviews 2009, 89: 27-71.

[22] Bass N.M.. :" Drug-Induced Liver Disease". In: Current Diagnosis and Treatment in Gastroenterology, Friedman, S., K. Mcquaid and J. Grendell (Eds.). 2nd Edn., McGraw-Hill Professional, New York 2003, pp: 664-679.

[23] Batcioglu K,Ozturk F, Ucar M, Ozturk IC andVardi N,: "Carbon tetrachloride-induced nephrotoxicity and protective effect of betaine in Sprague-Dawley rats" .Urology. 2003 ,62(2):353-6.

[24] Beckman JA, Creager MA and Libby P. :"Diabetes and atherosclerosis: epidemiology, pathophysiology, and management". JAMA. 2002, 287(19):2570-81. 
[25] Beckman, J. S. :"Oxidative damage and tyrosine nitration from peroxynitrite".Chem. Res. Toxicol. 1996 , 9, 836-844.

[26] Bellomo R. :"The epidemiology of acute renal failure: 1975 versus 2005".Curr Opin Crit Care. 2006 , 12(6):557-560.

[27] Benichou C. :"Criteria of drug-induced liver disorders. Report of an International Consensus Meeting". J Hepatol. 1990, 11: 272-276.

[28] Bennett W. :"Lead Nephropathy". Kidney Int 1985, 28:212-20.

[29] Bentli R, Ciftci O, Cetin A, Unlu M, Basak N and Cay M. :"Oral administration of hesperidin, a citrus flavonone, in rats counteracts the oxidative stress, the inflammatory cytokine production, and the hepatotoxicity induced by the ingestion of 2,3,7,8-tetrachlorodibenzo-p-dioxin (TCDD) "..Eur Cytokine Netw. 2013 Jun;24(2):91-6

[30] Berger ML, Bhatt H, Combes B and Estabrook RW. :"CClHYPERLINK "http://www.ncbi.nlm.nih.gov/pubmed/3943788"4HYPERLINK ～"http://www.ncbi.nlm.nih.gov/pubmed/3943788"induced toxicity in isolated hepatocytes: the importance of direct solvent injuryHYPERLINK "http://www.ncbi.nlm.nih.gov/pubmed/3943788""HYPERLINK

"http://www.ncbi.nlm.nih.gov/pubmed/3943788".Hepatology. 1986, 6(1):36-45.

[31] Berker K, Guclu K, Tor I and Apak R. :"Comparative evaluation of Fe (III) reducing power-based antioxidant capacity assays in the presence of phenanthroline, batho-phenanthroline, tripyridyltriazine (FRAP), and ferricyanide reagents". Talanta. 2007; 72, 1157-1165.

[32] Bernard A. :"Cadmium and its adverse effects on human health". Indian J Med Res 2008, 128:557-64.

[33] Bertolami M.C. :"Mechanisms of hepatotoxicity". Arq Bras de Cardiol. 2005, 85(5): 25-27.

[34] Beune PH and Lecoeur J. :"Immunotoxicity of the liver: adverse reactions to drugs". J Hepatol 1997, 26(Suppl 2):37-42.

[35] Beutler E, Duron O, Kelly MB,:" Improved method for the determination of blood glutathione". J.Lab.Clinical Medicine (1963) 16,882

[36] Bhattacharya H ,Gomez G.D.R and Lun L :"Biochemical Effects to Toxicity of CCl4 on Rosy Barbs". Our Nature .2005,3:20-25.

[37] Bissell D., Gores G., Laskin D. and Hoofnagle J.H. :"Drug-induced liver injury: mechanisms and test systems". Hepatol. 2001, 33: 1009-1013

[38] Bissell D., Gores G., Laskin D. and Hoofnagle J.H. :"Drug-induced liver injury: mechanisms and test systems". Hepatol. 2001, 33: $1009-1013$.

[39] Bjornsson E. "Hepatotoxicity associated with antiepileptic drugs".Acta Neurol Scand. 2008, 118: 281-290.

[40] Bondy, S. C. :"Ethanol toxicity and oxidative stress". Toxicol. Lett. 1992 , 63: 231-241.

[41] Booth AN, Jones FT and Dee DS :"//Metabolic fate of hesperidin, eriodictyol, homoeriodictyol, and diosmin" Biochem.1958 , 230: 661-668.

[42] Bort R., Ponsoda X., Jover R., Gomez-Lechon M.J. and Castell J.V :"Diclofenac toxicity to hepatocytes: a role for drug metabolism in celltoxicity". J Pharmacol Exp Ther 1999, 288: 65-72.

[43] Brattin WJ, Glende EA Jr. and Recknagel RD. :"Pathological mechanisms in carbon tetrachloride hepatotoxicity". J Free Radical Biol Med.1985, 1:27-38.

[44] Breen D.P., Marinaki A.M., Arenas M. and Hayes P.C. : "Pharmacogenetic association with adverse drug reactions to azathioprine immunosuppressive therapy following liver transplantation". Liver Transpl. 2005, 11: 826-833.

[45] Bricquir Y., Larrey D., Blanc P., Pageaux G.P. and Michel H.: "Tianeptine-an instance of drug-induced hepatotoxicity predicted by prospective experimental studies". J Hepatol. 1994, 21: 771-773.

[46] Brody G.L. and Sweet R.B. :"Halothane anesthesia as a possible cause of massive hepatic necrosis". Anesthesiol. 1963, 24: 29-37.

[47] Buckalew VM. :"Nonsteroidal anti-inflammatory drugs and the kidney". In:Greenberg A, editor. A Primer on Kidney Diseases. San Diego: Academic Press. 1998,291-297.

[48] Cadenas E:"Basic mechanisms of antioxidant activity". Biofactors 1997 , 6:391-397.

[49] Cekmen M., Ilbey Y. O., Ozbek E., Simsek A., Somay A. and Ersoz C.:"Curcumin prevents oxidative renal damage induced by acetaminophen in rats". Food and Chemical Toxicology 2009 , 47: 1480-1484.

[50] Cesarone MR, Belcaro G, Rohdewald P, Pellegrini L, Ledda A, Vinciguerra G, et al :"Comparison of Pycnogenol and Daflon in treating chronic venous insufficiency: a prospective, controlled study". Clin Appl Thromb Hemost. 2006, 12(2):205-12.

[51] Chatterjee ML, Katiyar SK, Mohan RR and Agarwal R. :"A Flavonoid Antioxidant, Silymarin, Affords Exceptionally High Protection against Tumor Promotion in the SENCAR Mouse Skin Tumorigenesis Model1". Cancer Research. 1999; 59: 622-632.

[52] Chen MC, Ye YY, Ji G and Liu JW. :"Hesperidin upregulates heme oxygenase-HYPERLINK "http://www.ncbi.nlm.nih.gov/pubmed/20170153"1 HYPERLINK "http://www.ncbi.nlm.nih.gov/pubmed/20170153"to 
attenuate hydrogen peroxide-induced cell damage in hepatic LHYPERLINK "http://www.ncbi.nlm.nih.gov/pubmed/20170153"02 "http://www.ncbi.nlm.nih.gov/pubmed/20170153"cells". J Agric Food Chem. 2010 ,58(6):3330-5.

[53] Chen, Q., and Cederbaum, A. I. :"Cytotoxicity and apoptosis produced by cytochrome P4502E1 in Hep G2 cells". Mol. Pharmacol. 1998, 53: 638-648.

[54] Chen, Q., Galleano, M., and Cederbaum, A. I. :"Cytotoxicity and apoptosis produced by arachidonic acid in HepG2 cells overexpressing human cytochrome P4502E1". J. Biol. Chem. . 1997, 272: 14352-14541

[55] Chitturi S. and George J. :"Hepatotoxicity of commonly used drugs: nonsteroidal anti-inflammatory drugs, antihypertensives, antidiabetic agents, anticonvulsants, lipid lowering agents, psychotropic drugs". Semin Liver Dis. 2002, 22: $169-183$.

[56] Cirico TL and Omaye ST. :"Additive or synergetic effects of phenolic compounds on human low density lipoprotein oxidation". Food Chem Toxicol. 2006 , 44(4):510-6.

[57] Coco TJ and Klasner AE. :"Drug-induced rhabdomyolysis". Curr Opin Pediatr.2004 , 16(2):206-210.

[58] Cohen, S. D., Pumford, N. R., Khairallah, E. A., Boekelheide, K., Pohl, L. R.,Amouzadeh, H. R., and Hinson, J. A.:"Selective protein covalent binding and target organ toxicity". Toxicol. Appl. Pharmacol. 1997, 143: 1-12.

[59] Corda S., Laplace C., Vicaut E., and Duranteau, J.:"Rapid reactive oxygen species production by mitochondria in endothelial cells exposed to tumor necrosis factor-alpha is mediated by ceramide”. American Journal of Respiratory Cell and Molecular Biology 2001, 24: 762-768.

[60] Costet P, Luo Y, Wang $\mathrm{N}$ and Tall AR. :"Sterol-dependent transactivation of the ABCHYPERLINK "http://www.ncbi.nlm.nih.gov/pubmed/10858438"1 HYPERLINK "http://www.ncbi.nlm.nih.gov/pubmed/10858438"promoter by the liver X receptor/retinoid X receptor". J Biol Chem. 2000, 275(36):28240-5.

[61] Cronin R. E.:“CContrast-induced nephropathy: pathogenesis and prevention”. Pediatric Nephrology 2010 , 25 : $191-204$.

[62] Day AJ, DuPontMS, Ridley S, Rhodes M, Rhodes M J.C ,Michael R.A., et al. :"Deglycosylation of flavonoid and isoflavonoid glycosides by human small intestine and liver $\beta$-glucosidase activity" FEBS Letters 1998, 436:71-75.

[63] Dayer JM, Feige U, Edwards and Burger D.. :" CK 3rd Anti-interleukin-HYPERLINK "http://www.ncbi.nlm.nih.gov/pubmed/11333344"1 HYPERLINK "http://www.ncbi.nlm.nih.gov/pubmed/11333344"therapy in rheumatic diseases". Curr Opin Rheumatol. 2001, 13(3):1706.

[64] DeLeve L, Wang X, Kuhlenkamp J and Kaplowitz N. :"Toxicity of azathioprine and monocrotaline in murine sinusoidal endothelial cells and hepatocytes: the role of glutathione and relevance to hepatic venooclusive disease". Hepatology 1996, 23:589-99.

[65] Deleve, L.D. and N. Kaplowitz,. :"Prevention and Therapy of Drug-Induced Hepatic Injury". In: Therapy of Digestive Disorders: A Companion to Sleisenger and Fordtran Gastrointestinal and Liver Disease", Wolfe, M. (Ed.). WB Saunders, Philadelphia 2000, pp: 334-348.

[66] Desmet, V.J., van Eyken P. and RoskamsT. :"Histopathology of vanishing bile duct diseases". Adv. Clin. Pathol. 1998, 2: 87-99.

[67] Dianzani, M. U.:"Lipid peroxidation in ethanol poisoning: A critical reconsideration". Alcohol 1985 , 20:161-173

[68] Ding F, Sun Y, Diao JX, Li XN, Yang XL, Sun Y, et al :"Features of the complex of food additive hesperidin to hemoglobin". J Photochem Photobiol B. 2012 ,106:53-60.

[69] Dix K.J., Coleman D.P. and Jeffcoat A.R. :"Comparative metabolism and disposition of gemfibrozil in male and female Sprague-Dawley rats and Syrian golden hamsters". Drug Metab Dispos. 1999, 27: 138-146

[70] Donnelly R, Idris I and Forrester JV. :" Protein kinase C inhibition and diabetic retinopathy: a shot in the dark at translational research". Br J Ophthalmol. 2004, 88(1): 145-151.

[71] Duffield J.S., Forbes S.J., Constandinou C.M., Clay S., Partolina M., Vuthoori S.et al :"Selective depletion of macrophages reveals distinct, opposing roles during liver injury and repair". J. Clin. Invest. 2005, 115:56-65

[72] Efrati S., Berman S. and Siman-Tov Y.:"N-acetylcysteine attenuates NSAID-induced rat renal failure by restoring intrarenal prostaglandin synthesis". Nephrology Dialysis Transplantation 2007 , 22: 1873-1881.

[73] El Sisi, A.E.D., Earnest, DL., and Sipes, I.G. :"Vitamin A potentiation of carbon tetrachloride hepatoxicity: role of liver mcrophages and active oxygen species ". Toxicol . App1. Phamacol. 1993b, 119: 295-301.

[74] Elavarasan J, Velusamy P, Ganesan T, Ramakrishnan SK, Rajasekaran D and Periandavan K. :" Hesperidin-mediated expression of NrfHYPERLINK "http://www.ncbi.nlm.nih.gov/pubmed/22943178"2 HYPERLINK "http://www.ncbi.nlm.nih.gov/pubmed/22943178"and upregulation of antioxidant status in senescent rat heart". J Pharm Pharmacol. 2012 , 64(10):1472-82. 
[75] Elisson E. and Kenna J.G. :"Cytochrome P4502E1 is a cell surface auto antigen in halothane hepatitis". Mol Pharmacol. 1996, 50: 573-582.

[76] Erlund I.T, Kosonen,G, Alfthan,J.,Mäenpää,K. „Perttunen.J. ,Kenraali.J., et al. :"Pharmacokinetics of quercetin from quercetin aglycone and rutin in healthy volunteers". Eur J Clin Pharmacol .2000, 56: 545-553.

[77] Ernesto S. and \%52 Robles-Osorio M.L. :"Renal health and the environment: heavy metal nephrotoxicity" Nefrologia $2012,32(3): 279-286$

[78] Etchason J.A., Miller T.D., Squires R.W., Allison T.G., Gau G.T. and Marttila J.K. :"Niacin-induced hepatitis: a potential side effect with low-dose time-release niacin". Mayo Clin Proceed. 1991, 66: 23-28.

[79] Etim O E, Akpan E J and I F Usoh :"Hepatotoxicity of carbon tetrachloride: protective effect of Gongronema latifolium" Pakistan journal of pharmaceutical sciences (Impact Factor: 1.1). 2008; 21(3):268-74.

[80] Ezz M, Hamdy G and Abd El Atti M.:"The Synergistic Hepatoprotective Effect of Curcumin aAnd Ginger Against Carbon Tetrachloride Induced- Liver Fibrosis in Rats". Australian Journal of Basic and Applied Sciences, 2011 (9): $1962-$ 1971.

[81] Fahmy S and Hamdi S.:" Antioxidant effect of the Egyptian freshwater Procambarus clarkii extract in rat liver and erythrocytes". African Journal of Pharmacy and Pharmacology, 5(6),776-785, June 2011

[82] Faulds CB, Plumb GW, Morgan MA, Williamson, G. Day AJ, Canada FJ, et al :"Dietary flavonoid and isoflavone glycosides are hydrolysed by the lactase site of lactase phlorizin hydrolase". FEBS Lett. 2000 , 468: 166-170.

[83] Fernandez-Checa and Kaplowitz :" hepatic mitochondrial glutathione : Transport and role in disease and toxicity ".Toxicol Applied Pharm 2005, 204:263-273

[84] Filho CB, Del Fabbro L, de Gomes MG, Goes AT, Souza LC, Boeira SP ,et al.:" Kappa-opioid receptors mediate the antidepressant-like activity of hesperidin in the mouse forced swimming test". Eur J Pharmacol. 2013, 698(1-3):286-91.

[85] Fitzgeorge RB, Fitzgeorge SA and Keevil CW. :"Routes of intoxication". In: G.A. Codd, T.M. Jefferies, C.W. Keevil and C. Potter, Editors, Detection methods for cyanobacterial toxins. Royal Society of Chemistry. 1994; 69-74.

[86] Flora, S.: "Role of free radicals and antioxidant in health and disease". Cell Mol.Biol 2007, (53): 1-2.

[87] Forbes G.M., Jeffrey G.P., Shilkin K.B. and Reed W.D.: "Carbamazepine hepatotoxicity: Another case of the vanishing bile duct syndrome". Gastroenterol. 1992, 102: 1385-1388.

[88] Freeman BL, Eggett DL and Parker TL. :"Synergistic and antagonistic interactions of phenolic compounds found in navel oranges". J Food Sci. 2010, 75(6):C570-6.

[89] Friedman SL.:"Mechanisms of hepatic fibrogenesis". Gastroenterology. 2008;134:1655-1669.

[90] Fromenty B., Freneaux E., Labbe G., Deschamps D., Larrey D., Letteron P. and Pessayre D. :"Tianeptine, a new tricyclic antidepressant metabolized by $\beta$-oxidation of its heptanoic side chain, inhibits the mitochondrial oxidation of medium and short chain fatty acids in mice". Biochem Pharmacol. 1989, 38: 3743-3751.

[91] Galati G and O’brien PJ. :"Flavonoids and Isoflavones (Phytoestrogens): Absorption, Metabolism, and Bioactivity". Free Radical Biology \& Medicine. 2004; 37(3): 287-303.

[92] Galicia-Moreno M.:"1N-acetylcysteine prevents carbon tetrachloride-induced liver cirrhosis: role of liver transforming growth HYPERLINK "\%26from=/19398917/related\%22N-acetylcysteine\%20prevents\%20carbon\%20tetrachlorideinduced $\% 20$ liver $\% 20$ cirrhosis:\%20role $\% 20$ of $\% 20$ liver $\% 20$ transforming $\% 20$ growth $\% 20$ HYPERLINK $\% 20 \% 22 \mathrm{https}: / / \mathrm{ww}$ w.ncbi.nlm.nih.gov/m/pubmed/19398917/?i=1\&from=/19398917/related"factor-beta and oxidative stress."factor-beta and oxidative stress.". Eur J Gastroenterol Hepatol. 2009 ,21(8):908-14.

[93] Galley HF :_/"Can acute renal failure be prevented". J R Coll Surg Edinb 2000 , 45 (1): 44-50

[94] Gandhi C, Upaganalawar A and Balaraman R. :"Protection against in vivo focal myocardial ischemia/reperfusion injuryinduced arrhythmias and apoptosis by hesperidin". Free Radic Res. 2009, 43(9):817-27.

[95] Gao H, Li G, Lou M, Li X, Wei X and Wang J:"Hepatoprotective effect of Matrine salvianolic acid B salt on Carbon Tetrachloride-Induced Hepatic Fibrosis".Journal of Inflammation 2012, 9:16

[96] Ghosh J., Das J., Manna P., and Sil P. C.:"Acetaminophen induced renal injury via oxidative stress and TNF-alpha production: therapeutic potential of arjunolic acid”. Toxicology 2010, 268: 8-18.

[97] Giustarini D., Dalle-Donne I., Paccagnini E., Milzani A. and Rossi R.:"Carboplatin-induced alteration of the thiol homeostasis in the isolated perfused rat kidney". Archives of Biochemistry and Biophysics 2009, 488: 83-89.

[98] Gonzalez L:,Perez AJ, Courel M and Sobrado J, "Acute renal failure after topical application of carbon tetrachloride". Lancet .1987,1:515-516.

[99] Graham DJ, Staffa JA and Shatin D:" Incidence of hospitalized rhabdomyolysis in patients treated with lipid-lowering drugs". JAMA.2004, 292(21):2585-2590.

[100] Gruchalla, R.S. :" Clinical assessment of drug-induced disease". Lancet 2000, 356: 1505-1511.

[101] Guder WG, Zawta B et al. :"The Quality of Diagnostic Samples". 1st ed. Darmstadt: GIT Verlag; 2001; p. 14-5 
[102] Guengerich, F. P., Kim, D. H. and Iwasaki, M. :"Role of human cytochrome P450 IIE1 in the oxidation of many low molecular weight cancer suspects". Chem. Res. Toxicol. 1990 , 14: 168-179.

[103] Gulmez, M., Guven, A. and GuvenA. "The effect of kefir on the activities of GSH-PX, GST, CAT, GSH, and LPO levels in carbontetrachloride - induced mice tissues". J. Vet Med B Infect Dis Vet Public Health. $2003,50: 412-416$.

[104] Guo X and Nzerue C, :"How to prevent, recognize, and treat drug-induced nephrotoxicity". Clevekand Clinic Journal Of Medicine 2002, 69: 289-312

[105] Hagen TM, Vinarsky V, Wehr CM and Ames BN. :" (R)-alpha-lipoic acid reverses the age-associated increase in susceptibility of hepatocytes to tert-butylhydroperoxide both in vitro and in vivo"..Antioxid Redox Signal. 2000 Fall;2(3):473-83

[106] Haller C. and Hizoh I.:"The cytotoxicity of iodinated radiocontrast agents on renal cells in vitro". Investigative Radiology 2004, 39: 149-154.

[107] Hardin BL. :" Carbon tetrachloride poisoning; a review". Ind Med Surg. 1954, 23:93-105

[108] Hart, S. G., Cartun, R. W., Wyand, D. S., Khairallah, E. A., and Cohen, S. D. :" Immunohistochemical localization of acetaminophen in target tissues of the CD-1 mouse: Correspondence of covalent binding with toxicity". Fund. Appl. Toxicol. 1995 , 24: 260-274.

[109] Hashkes, P.J., W.F. Balistreri, K.E. Bove, E.T. Ballard and M.H. Passo. :"The relationship of hepatotoxic risk factors and liver histology in methotrexate therapy for juvenile rheumatoid arthritis". J. Pediatr. 1999, 134: 47-52.

[110] Helliwell P.S. and Taylor W.J. :"Treatment of psoriatic arthritis and rheumatoid arthritis with disease modifying drugscomparison of drugs and adverse reactions". J Rheumatol. 2008, 35: 472-476.

[111] Henry and John Bernard, "Clinical Diagnosis and Management by Laboratory Methods", 20th Edition, W.B. Saunders Company, Philadelphia (2001)

[112] HenryJ. :" Clinical Diagnosis and Management by Laboratory Methods".W.B. Saunders and Co., Philadelphia, 1974, PA. p 361

[113] Hinson, J. A., Michael, S. L., Ault, S. G., and Pumford, N. R.:"Western blot analysis for nitrotyrosine protein adducts in livers of saline-treated and acetaminophen-treated mice". Toxicol. Sci. 2000, 53: 467-473

[114] Hollman, P., Buysman, M. P., van Gameren, Y., Cnossen, E., de Vries, J. and Katan, M. :"The sugar moiety is a major determinant of the absorption of dietary flavonoid glycosides in man". Free Rad. Res. 1999, 31:569-573.

[115] Honohan T, 55Hale RL, 55Brown JP and 55Wingard RE Jr. :".aSynthesis and metabolic fate of hesperetin-HYPERLINK "031?journalCode=jafcau"Synthesis and metabolic fate of hesperetin-3-14C"3HYPERLINK "031?journalCode=jafcau"Synthesis and metabolic fate of hesperetin-3-14C"-HYPERLINK "031?journalCode=jafcau"Synthesis and metabolic fate of hesperetin-3-14C"14HYPERLINK "031?journalCode=jafcau"Synthesis and metabolic fate of hesperetin-3-14C"C". J Agric Food Chem. 1976,(5):906-11.

[116] Horcajada MN, Habauzit V, Trzeciakiewicz A, Morand C, Gil-Izquierdo A, Mardon J, et al.:"Hesperidin inhibits ovariectomized-induced osteopenia and shows differential effects on bone mass and strength in young and adult intact rats". J Appl Physiol 2008,104(3):648-54.

[117] Horst D., Grace N. and Le Compte P. :"Prolonged cholestasis and progressive hepatic fibrosis following imipramine therapy". Gastroenterology. 1980, 79: 550-554.

[118] Hsiao G , Shen M , Lin K, Lan M,Wu L and Chou D. :" Antioxidative and hepatoprotective effects of antrodia camphorata extract " J. Agric. Food Chem. 2003, 51, 3302-3308.

[119] Huerta-Alardin AL, Varon J and Marik PE. :"Bench-to-bedside review: rhabdomyolysis :an overview for clinicans". Crit Care. $2005,9(2): 158-169$.

[120] Hwang SL and Yen GC. :" Effect of hesperetin against oxidative stress via ER- and TrkA-mediated actions in PCHYPERLINK "http://www.ncbi.nlm.nih.gov/pubmed/21486081"12 HYPERLINK "http://www.ncbi.nlm.nih.gov/pubmed/21486081"cells". J Agric Food Chem. 2011 , 59(10):5779-85.

[121] Ichikawa, I.,Kiyama, S. and Yoshioka, T. "Renal antioxidant enzymes: their regulation and function." Kidney. Int. 1994, 45: $1-9$.

[122] Iio A, Ohguchi K, Iinuma M, Nozawa $\mathrm{Y}$ and Ito $\mathrm{M}$. :" Hesperetin upregulates ABCAHYPERLINK "http://www.ncbi.nlm.nih.gov/pubmed/22429094"1 HYPERLINK "http://www.ncbi.nlm.nih.gov/pubmed/22429094"expression and promotes cholesterol efflux from THP-HYPERLINK "http://www.ncbi.nlm.nih.gov/pubmed/22429094"1 HYPERLINK "http://www.ncbi.nlm.nih.gov/pubmed/22429094"macrophages". J Nat Prod. 2012 ,75(4):563-6.

[123] Ilbey Y.O., Ozbek E. and Cekmen M. :"Melatonin prevents acetaminophen-induced nephrotoxicity in rats”. International Urology and Nephrology 2009, 41: 695-702,

[124] Ishak K. and Irey N.: " Hepatic injury associated with the phenothiazines". Arch Path. 1972, 93: 283-304.

[125] Ismail MH and Pinzani M : "Reversal of liver fibrosis". Saudi J Gastroenterol .2009 , 15 (1): 72-9. 
[126] Jaeschke H, Gores GJ, Cederbaum AI, Hinson JA, Pessayre D and Lemasters JJ :"Mechanisms of hepatotoxicity". Toxicol. Sci. 2002, 65 (2): 166-76

[127] Jaffe,M.Z., :"About generates the precipitation which picric acid in normal urine and via a new reaction of creatinine". Z Physiol Chem 1886;10:391-400.

[128] Jean T and Bodinier MC.:"Mediators involved in inflammation: effects of Daflon $500 \mathrm{mg}$ on their release".Angioloy. 1994, 45, 554-9.

[129] Jeffrey LA and Allan T. :"Handbook of Psychiatric Drugs". JohnWiley and Sons Ltd., Chichester UK 2006 ,p 34.

[130] Jeong H, Lee JY, Jang EJ, Lee EH, Bae MA, Hong JH, et al. :"Hesperedin promotes MyoD-induced myogenic differentiation in vitro and in vivo". Br J Pharmacol. 2011 , 163(3):598-608.

[131] Jeong HJ, Choi Y, Kim KY, Kim MH and Kim HM.. :"C-kit binding properties of hesperidin (a major component of KMPHYPERLINK "http://www.ncbi.nlm.nih.gov/pubmed/21559359"6HYPERLINK "http://www.ncbi.nlm.nih.gov/pubmed/21559359") as a potential anti-allergic agent". Plos One. 2011, 6(4):e19528.

[132] Jin, M.J., Kim, U., Kim, I.S., Kim, Y.,Kim, D.H., Han, S.B., et al :"Effects of gut microflora on pharmacokinetics of hesperidin: a study on non-antibiotic and pseudo-germ-free rats". J. Toxicol. Environ. Health A. 2010, 73:1441-1450.

[133] Jobanputra P., Amarasena R., Maggs F., Jubb R. and Homer D. : "Hepatotoxicity associated with sulfasalazine in inflammatory arthritis: acase series from a local surveillance of serious adverse events". BMC Musculoskelet Disord. 2008, 9: 48.

[134] Johnson S., Chan J. and Bennett C. :"Hepatotoxicity after prophylaxis with a nevirapine-containing antiretroviral regimen". Ann Intern Med. 2002,137: 146-147.

[135] Jones, D. P., Carlson, J. L., Mody, V. C., Cai, J. Y., Lynn, M. J., and Sternberg, P. :"Redox state of glutathione in human plasma". Free Radic. Biol. Med. 2000 , 28, 625-635.

[136] Joseph SB, McKilligin E, Pei L, Watson MA, Collins AR, Laffitte BA, et al :"Synthetic LXR ligand inhibits the development of atherosclerosis in mice". Proc Natl Acad Sci USA. 2002 , 99(11):7604-9.

[137] Joshi G, Sultana R, Tangpong J, Cole MP, St Clair DK and Vore M et al. :"Free radical mediated oxidative stress and toxic side effects in brain induced by the anti cancer drug adriamycin: Insight into chemobrain". Free Radical Research. 2005; 39(11): 1147-1154.

[138] Kadiiska MB, Gladen BC, Baird DD, Germolec D and Graham LB:"Biomarkers of oxidative stress study II: are oxidation products of lipids, proteins, and DNA markers of CCl4 poisoning" Free Radical Biology \& medicine 2005, 38: 698-710

[139] Kalpana KB, Devipriya N, Srinivasan M and Menon VP. :" Investigation of the radioprotective efficacy of hesperidin against gamma-radiation induced cellular damage in cultured human peripheral blood lymphocytes". Mutat Res. 2009 , 676(1-2):54-61.

[140] Kanda M., Ihara Y. and Murata H. :"Glutaredoxin modulates platelet-derived growth factor-dependent cell signaling by regulating the redox status of low molecular weight protein- tyrosine phosphatase". Journal of Biological Chemistry. 2006 , 281: 28518-28528.

[141] Kanes K, Tisserat B, Berhow M and Vandercook C :"Phenolic composition of various tissuesHYPERLINK "http://www.sciencedirect.com/science/article/pii/003194229385237L" HYPERLINK "http://www.sciencedirect.com/science/article/pii/003194229385237L" of rutaceae species" Phytochemistry 1993//, HYPERLINK "4\%22,\%2032"32: 967-974

[142] Kang, J.-O., Kim, S.-J., Kim, H.2001 :"Effect of astaxanthin on the hepatotoxicity, lipid peroxidation and antioxidative enzymes in the liver of CCl4-treated rats " Methods Find Exp Clin Pharmacol. 2001, Mar;23(2):79-84.

[143] Kaplowitz N and DeLeve LD. :"Mechanisms of cell death and relevance to drug hepatotoxicity".In: Drug-induced liver disease.,eds. New York: Marcel Dekker, 2002, p85-95.

[144] Kaplowitz N. :"Biochemical and cellular mechanisms of toxic liver injury".Semin Liver Dis 2002, 22:137-44.

[145] Kaplowitz N. :"Drug-induced liver disorders: introduction and overview".In: Kaplowitz N, DeLeve LD", eds. Druginduced liver disease. NewYork: Marcel Dekker. 2002,1-13.

[146] Kaplowitz N. :"Drug-Induced Liver Injury" Clinical Infectious Diseases. 2004, 38(Suppl 2):S44-8

[147] Kaplowitz N. :"Mechanisms of liver cell injury". J Hepatol 2000, 32:39-47.

[148] Kaster MP, Budni J, Santos AR and Rodrigues AL. :"Pharmacological evidence for the involvement of the opioid system in the antidepressant-like effect of adenosine in the mouse forced swimming test". Eur J Pharmacol. 2007 , 576(1-3):91-8.

[149] Katsinelos, P., T. Vasiliadis and P. Xiarchos. :" Ursodeoxycholic acid (UDCA) for the treatment of amoxycillinclavulanate potassium (Augmentin) -induced intra-hepatic cholestasis: Report of two cases". Eur. J. Gastroenterol. Hepatol. 2000, 12: 365-368

[150] Kawaguchi K,MizunoT,Aida K and Uchino K. :"Hesperedine as an inhibitor of lipase form porcine pancreas and Pseudomonas" .Biosci Biotech Biochem. 1997, 61:102-104. 
[151] Kawai Y., Nakao T., Kunimura N., Kohda Y., and Gemba M. : "Relationship of intracellular calcium and oxygen radicals to cisplatin-related renal cell injury". Journal of Pharmacological Sciences. 2006, $100: 65-72$.

[152] Khan MR, Rizvi W, Khan GN, Khan RA and Shaheen S."Carbon tetrachloride-induced nephrotoxicity in rats: protective role of Digera muricata".J Ethnopharmacol. 2009 Feb 25;122(1):91-9

[153] Khan R. A., Khan M. R and Sahreen S. "CCl4-induced hepatotoxicity: protective effect of rutin on p53, CYP2E1 and the antioxidative status in rat" BMC Complementary and Alternative Medicine. 2012, 12:178.

[154] Kim H Y, Kim J K, Choi J H, Jung J Y, Oh W Y, Kim D C et al ."Hepatoprotective effect of pinoresinol on carbon tetrachloride-induced hepatic damage in mice". J. Pharmacol. Sci. 2010, 112(1):105-112.

[155] Kitteringham NR. :" Drug-protein conjugation and its immunological consequences". Drug Metab Rev 1990, 22:87-144.

[156] Klaassen CD, Liu J and Diwan BA. :"Metallothionein protection of cadmium toxicity". Toxicol Appl Pharmacol 2009 , 238:215-20.

[157] Knowles S, Uetrecht J and Shear N. :" Idiosyncratic drug reactions: the reactivemetabolite syndrome". Lancet 2000, 356:1587-91.

[158] Ko KM, Ip SP, Poon MKT, Wu SS, Che CT and Ng KH, et al. :"Effect of lignan enriched Fructus schisandrae extract on hepatic glutathione status in rats: protection against carbon tetrachloride toxicity". Planta Med 1995; 61 : 134-7.

[159] Ko WC, Shih CM, Lai YH, Chen JH and Huang HL. :"Inhibitory effects of flavonoids on phosphodiesterase isozymes from guinea pig and their structure-activity relationships". Biochem Pharmacol. 2004 , 68(10):2087-94.

[160] Kodama K, 55Oguchi K and 55Tsuji M.:"Protective effect of S-adenosyl-L-methionine against CCl4-induced hepatotoxicity in cultured hepatocytes". Jpn J PharmacolHYPERLINK "http://www.ncbi.nlm.nih.gov/pubmed/2313931". $1990,52(2): 209-14$.

[161] Kodner CM and Kudrimoti A. :" Diagnosis and management of acute interstitial nephritis". Am Fam Physician. 2003,67(12):2527-2534.

[162] Koop, D. R. :"Oxidative and reductive metabolism by cytochrome P4502E1". FASEB J. 1992 , 6: 724-730.

[163] Kremer, J.M.,. Furst D.E, Weinblatt M.E. and Blotner. S.D.:"Significant changes in serum AST across hepatic histological biopsy grades: Prospective analysis of 3 cohorts receiving methotrexate therapy for rheumatoid arthritis". J. Rheumatol. 1996, 23: 459-461.

[164] Krogholm KS, Bredsdorff L and Knuthsen P. :"Relative bioavailability of the flavonoids quercetin, hesperetin and naringenin given simultaneously through diet". Eur J Clin Nutr. 2010,64:432-435.

[165] Kucuktulu E. :"Protective effect of melatonin against radiation induced nephrotoxicity in rats". Asian Pac J Cancer Prev.2012, 13(8):4101-5

[166] Kumar B, Gupta SK, Srinivasan BP, Nag TC, Srivastava S and Saxena R.. :"Hesperetin ameliorates hyperglycemia induced retinal vasculopathy via anti-angiogenic effects in experimental diabetic rats". Vascul Pharmacol. 2012, 57(56):201-7.

[167] Laetitia K, Alain B, Catherine R, Pierre-Emmanuel P et al . ":Carbon tetrachloride-mediated lipid peroxidation induces early mitochondrial alterations in mouse liver." Laboratory Investigation 2012, Vol. 92 Issue 3, p396.

[168] Laferrère B, Abraham C, Russell CD and Bowers CY. :"Growth hormone releasing peptide-HYPERLINK "http://www.ncbi.nlm.nih.gov/pubmed/15699539"2 "http://www.ncbi.nlm.nih.gov/pubmed/15699539"(GHRP-HYPERLINK "http://www.ncbi.nlm.nih.gov/pubmed/15699539"2HYPERLINK "http://www.ncbi.nlm.nih.gov/pubmed/15699539"), like ghrelin, increases food intake in healthy men". J Clin Endocrinol Metab. 2005 , 90(2):611-4.

[169] Lampert S.M . :"Carbon tetrachloride in treatment of hookworm disease".Observation in twenty thousand cases 1922:JAMA, 79:2055.

[170] Landmesser U., Bahlmann F., Mueller M., Spiekermann S., Kirchhoff N. and Schulz S. :"Simvastatin versus ezetimibe: pleiotropic and lipid lowering effects on endothelial function in humans". Circulation. 2005,111: 2356-2363

[171] Langerak A. D. and Dreisbach L. P.. :"Chemotherapy regimens and cancer care", Landes Bioscience, Georgetown, Tex, USA, 2001.

[172] Leblanc M, Kellum JA, Gibney RT, Lieberthal W, Tumlin J and Mehta R. :"Risk factors for acute renal failure: inherent and modifiable risks". Curr Opin Crit Care. 2005 , 11(6):533-536.

[173] Lee YR, Jung JH and Kim HS. :"Hesperidin partially restores impaired immune and nutritional function in irradiated mice". J Med Food. 2011, 14(5):475-82.

[174] Leist M., Gantner F., Kunstle G. and Wendel A. :"Cytokine-mediated hepatic apoptosis". Rev Physiol Biochem Pharmacol. 1998, 133: 109-155.

[175] Levy, GN and; Brabec, MJ. :"Binding of carbon tetrachloride metabolites to rat hepatic mitochondrial DNA". Toxicol Lett. 1984, 22:229-234. 
[176] Lewis, J.H. and Zimmerman. H.J. :" Drug Induced Autoimmune Liver Disease". In: Autoimmune Liver Disease, Krawitt, E.L., R.H. Wiesner and M. Nishioka (Eds.). 2nd Edn., Elsevier, Amsterdam 1998, pp: 627-649.

[177] Li D, Mitsuhashi S and Ubukata M. "Protective effects of hesperidin derivatives and their stereoisomers against advanced glycation end-products formation". Pharm Biol. 2012, 50(12):1531-5.

[178] Li F, Ye L, Lin SM and Leung LK. :"Dietary flavones and flavonones display differential effects on aromatase (CYPHYPERLINK

"http://www.ncbi.nlm.nih.gov/pubmed/21741436"19HYPERLINK "http://www.ncbi.nlm.nih.gov/pubmed/21741436") transcription in the breast cancer cells MCF-HYPERLINK "http://www.ncbi.nlm.nih.gov/pubmed/21741436"7". Mol Cell Endocrinol. 2011 , 344(1-2):51-8.

[179] Lin JL, Yu CC, Lin-Tan D and Ho HH. :" Lead chelation therapy and urate excretion in patients with chronic renal diseases and gout". Kidney Int. 2001, 60:266-71.

[180] Liu L, Shan S, Zhang K, Ning ZQ, Lu XP and Cheng YY. :"Naringenin and hesperetin, two flavonoids derived from Citrus aurantium up-regulate transcription of adiponectin". Phytother Res.2008,22(10):1400-3.

[181] Loeper J, Descatoire V and Maurice M. :"Presence of functional cytochromeP450 on isolated rat hepatocyte plasma membrane". Hepatology1990,p 11:850-8.

[182] Loki A.L. and Rajamohan T :"Hepatoprotective and antioxidant effect of tender coconut water on Carbon tetrachloride induced hepatotoxicity in rat ".Indian J Biochem Biophys. 2003, 40(5):354-7.

[183] Loscalzo LM, Wasowski C, Paladini AC and Marder M. "Opioid receptors are involved in the sedative and antinociceptive effects of hesperidin as well as in its potentiation with benzodiazepines ."Eur $\mathbf{J}$ Pharmacol , 2008 . .13-306:(3)580

[184] Loscalzo LM, Yow TT, Wasowski C, Chebib M and Marder M.. :"Hesperidin induces antinociceptive effect in mice and its aglycone, hesperetin, binds to $\mu$-opioid receptor and inhibits GIRKHYPERLINK "http://www.ncbi.nlm.nih.gov/pubmed/21624389"1HYPERLINK "http://www.ncbi.nlm.nih.gov/pubmed/21624389"/HYPERLINK～"http://www.ncbi.nlm.nih.gov/pubmed/21624389"2 HYPERLINK "http://www.ncbi.nlm.nih.gov/pubmed/21624389"currents". Pharmacol Biochem Behav. 2011 , 99(3):33341.

[185] Luciani P, Deledda C, Rosati F, Benvenuti S, Cellai I, Dichiara F, et al :"Seladin-HYPERLINK "http://www.ncbi.nlm.nih.gov/pubmed/18499757"1 HYPERLINK "http://www.ncbi.nlm.nih.gov/pubmed/18499757"is a fundamental mediator of the neuroprotective effects of estrogen in human neuroblast long-term cell cultures". Endocrinology. 2008 , 149(9):4256-66.

[186] Magda K. Ezz, Germine M. Hamdy and Rasha M and Abd El Atti :"The Synergistic Hepatoprotective Effect of Curcumin And Ginger Against Carbon Tetrachloride Induced- Liver Fibrosis in Rats" Australian Journal of Basic and Applied Sciences 2011, 5(9): 1962-1971

[187] Mahmudur-Rahman R, Ng JC and Naidu R. :"Chronic exposure of arsenic via drinking water and its adverse health impacts on humans".Environ Geochem Health 2009, 31:189-200.

[188] Manach C, Manach C, Williamson G, Morand C, Scalbert A, and Rémésy C. :"Bioavailability and bioefficacy of polyphenols in humans. I. Review of HYPERLINK "http://www.ncbi.nlm.nih.gov/pubmed/15640486"97 HYPERLINK "http://www.ncbi.nlm.nih.gov/pubmed/15640486"bioavailability studies". Am J Clin Nutr. 2005 , 81:230S-42S.

[189] Manach C, Morand C, Gil-Izquierdo A, Bouteloup-Demange C and Re'me'sy C .: "Bioavailability in humans of the flavanones hesperidin and narirutin after the ingestion of two doses of orange juice". Eur J Clin Nutr 2003 ,57: $235-242$.

[190] Mandal AK, Sinha J, Mandal S, Mukhopadhyay S, Das N. :"Targeting of liposomal flavonoid to liver in combating hepatocellular oxidativedamage".. Drug Deliv 2002, 9:181-185

[191] Manibusan, M. K., Odin, M. and Eastmond, D. A. :"Postulated carbon tetrachloride mode of action: a review". J Environ Sci Health C Environ Carcinog Ecotoxicol Rev 2007, 25: 185-209

[192] Manjrekar, A Jisha P, Bag V, Adhikary P, Pai B, Hegde M et al :"Effect of Phyllanthus niruri Linn. treatment on liver, kidney and testes in CCl4 induced hepatotoxic rats" Indian J Exp Biol. 2008 ,46(7):514-20.

[193] Mark Berhow, Brent Tisserat, Katherine Kanes, and Carl Vandercook HYPERLINK "http://www.worldcat.org/title/survey-of-phenolic-compounds-produced-in-citrus/oclc/708405889":"HYPERLINK "http://www.worldcat.org/title/survey-of-phenolic-compounds-produced-in-citrus/oclc/708405889"Survey of phenolic compounds produced in citrus" In Technical Bulletin 1996, 158: no 1856.

[194] Markham KR. :" Techniques of Flavonoid Identification".Academic Press, London, 1982: 15-31.

[195] Markowitz GS and Perazella MA. :"Drug-induced renal failure: a focus on tubulointerstitial disease". Clin Chim Acta. 2005,351(1-2):31-47

[196] Masella R, Di Benedetto R, Vari R, Filesi C and Giovannini C.:"Novel mechanisms of natural antioxidant compounds in biological systems: Involvement of glutathione and glutathione related enzymes". Journal of Nutritional Biochemistry 2005 ,16: 577-586. 
[197] Mashour S, Turner JF and Merrell R. :"Acute renal failure, oxalosis, and vitamin C supplementation: a case report and review of the literature".Chest 2000, 118:561-563.

[198] Masubuchi Y., Yamada S. and Horie T . :"Possible mechanisms of hepatocyte injury induced by diphenylamine and its structurally related NSAIDS". J Pharmacol Exp Ther 2000, 292: 982-987

[199] Mathew TH. :"Drug-induced renal disease". Med J Aust 1992, 156:724-729.

[200] Matsumoto H, Ikoma Y, Sugiura M, Yano M and Hasegawa Y. :"Identification and quantification of the conjugated metabolites derived from orally administered hesperidin in rat plasma". J Agric Food Chem. 2004, 52(21):6653-9.

[201] Matzinger P. :"Tolerance, danger and the extended family". Annu RevImmunol 1994, 12:991-1045.

[202] McCullough PA, Adam A and Becker CR, :" CIN Consensus Working Panel. Risk prediction of contrast-induced nephropathy". Am J Cardiol. 2006 , 98(6A):27K-36K.

[203] McEwen BS. :"Invited review: Estrogens effects on the brain: multiple sites and molecular mechanisms". J Appl Physiol $.2001,91(6): 2785-801$.

[204] McNally and Peter F. :GI/Liver Secrets: with Student Consult Access. Saint Louis: C.V. Mosby 2006, p 618-7.

[205] Merten GJ, Burgess WP and Gray LV. :"Prevention of contrast-induced nephropathy with sodium bicarbonate: a randomized controlled trial".JAMA. 2004, 291(19):2328-2334

[206] Milenkovic D, Deval C, Dubray C, Mazur A and Morand C. :"Hesperidin displays relevant role in the nutrigenomic effect of orange juice on blood leukocytes in human volunteers: a randomized controlled cross-over study". Plos One. 2011, 6(11):e26669.

[207] Mitchell C, Couton D and Couty JP.:"Dual role of CCR2 in the constitution and the resolution of liver fibrosis in mice". Am J Pathol 2009, 174(5):1766-1775.

[208] Mitchell C, 55 Robin M, 55Mayeuf A, 55Mahrouf-Yorgov M, 55Mansouri A, 55 Hamard M et al :"Protection against hepatocyte mitochondrial dysfunction delays fibrosis progression in mice" Am J Pathol. 2009 , 175(5): $1929-1937$.

[209] Miwa Y, Mitsuzumi H, Sunayama T, Yamada M, Okada K, Kubota M, et al :"Glucosyl hesperidin lowers serum triglyceride level in hypertriglyceridemic subjects through the improvement of very low-density lipoprotein metabolic abnormality". J Nutr Sci Vitaminol (Tokyo). 2005, 51(6):460-70.

[210] Montilla M. P., Cabo J., Navarro M. C., Risco S., Jiménez J.,and Aneiros J:"The protective and curative action of Withania frutescens leaf extract against CCl4-induced hepatotoxicity" Physiotherapy Research 1990 , .46 (HYPERLINK "/issuetoc\%22\%20(4):"4HYPERLINK "/issuetoc\%22\%20(4):"): 212-215.

[211] Moradpour D, Altorfer J and Flury R, :"Chlorpromazine-inducing vanishing bile duct syndrome leading to biliary cirrhosis". Hepatology 1994, 20:1437-41.

[212] Morand C, Dubray C, Milenkovic D, Lioger D, Martin JF, Scalbert A, et al.:"Hesperidin contributes to the vascular protective effects of orange juice: a randomized crossover study in healthy volunteers". Am J Clin Nutr. 2011, 93(1):7380 .

[213] Morimoto, M., Zern, M. A., Hagbjork, A. L., Ingelman-Sundberg, M., and French, S. W. :"Fish oil, alcohol, and liver pathology: Role of cytochrome P450 2E1". Proc. Soc. Exp. Biol. Med. 1994 , 207: 197-205.

[214] Mork, H., O. Al-Taie, O. Klinge and M. Scheurlen. :"Successful therapy of persistent androgen-induced cholestasis with ursodeoxycholic acid". Z. Gastroenterol. 1997, 35: 1087-1091.

[215] Moss DW and Henderson AR :"Enzymes". In: Clinic al Chemistry, 2nd edn (Burtis CA, Ashwood ER, eds). Phi ladelphia: WB Saunders .1999, pp 735-896

[216] Mousa H M, Al-Qarawi A A, Ali B.A,El-Mougy S A.:"Protective effect of extracts from dates (Phoenix dactylifera L.) on carbon tetrachloride-induced hepatotoxicity in rats" Intern J Appl Res Vet Med. 2004, Vol. 2, No. 3.

[217] Mullen W, Archeveque MA, Edwards CA, Matsumoto H and Crozier A. :"Bioavailability and metabolism of orange juice flavanones in humans: Impact of a full-fat yogurt". J. Agric. Food Chem. 2008 , 56:11157-11164.

[218] Mumoli N, Cei M and Cosimi A. :"Drug-related hepatotoxicity". N. Engl. J. Med. 2006, 354 (20): 2191-3

[219] Murray R.I :"Creatinine". Kaplan A et al Clin chem. The C.V. Mosby Co. St Louis. Tornto.Princeton 1984:1261-1266 and 418.

[220] Nanji, A. A., Zhao, S., Sadrzadeh, S. M. H., Dannenberg, A. J., Tahan, S. R., and Waxman, D. J. :"Markedly enhanced cytochrome P450 2E1 induction and lipid peroxidation is associated with severe liver injury in fishoil-ethanol-fed rats". Alcohol Clin. Exp. Res. 1994 , 18: 1280-1285

[221] Nash K, Hafeez A and Hou S. :"Hospital-acquired renal insufficiency". Am J Kidney Dis. 2002 , 39(5):930-936.

[222] Naughton CA. :"Drug-induced nephrotoxicity". Am Fam Physician. 2008 , 78(6):743-50

[223] Neary NM, Small CJ, Wren AM, Lee JL, Druce MR, Palmieri C, et al :"Ghrelin increases energy intake in cancer patients with impaired appetite: acute, randomized, placebo-controlled trial". J Clin Endocrinol Metab. 2004 , 89(6):2832-6. 
[224] Németh K, Plumb GW and Berrin J-G :"Deglycosylation by small intestinal epithelial cell $\beta$-glucosidases is a critical step in the absorption and metabolism of dietary flavonoid glycosides in humans". Eur J Nutr .2003,42:29-42.

[225] Nielsen IL, Chee WS, Poulsen L, Offord-Cavin E, Rasmussen SE, Frederiksen H, et al. :"Bioavailability is improved by enzymatic modification of the citrus flavonoid hesperidin in humans: a randomized, double-blind, crossover trial". J Nutr. $2006,136(2): 404-8$.

[226] Nishikimi, M., Roa, N.A., Yogi, K.:" Measurement of superoxide dismutase". Biochem.Biophys. Res. Common, 1972,46:849-854.

[227] Njoku D., Laster M.J. and Gong D.H. :"Biotransformation of halothane, enflurane, isoflurane and desflurane to trifluoroacetylated liver proteins: association between protein acylation and hepatic injury". Anest Analg. 1997, 84: 173178.

[228] Nogueira, C.W., Zeni, G., and Rocha JBT :"Organoselenium and organotellurium compounds : toxicology and pharmacology". Chem. Rev. 2004 , 104: 6255-6285.

[229] Nones J, Costa AP, Leal RB, Gomes FC and Trentin AG. :"The flavonoids hesperidin and rutin promote neural crest cell survival". Cell Tissue Res. 2012, 350(2):305-15.

[230] Nordberg G, Chen L, Lei L, Jin T and Nordberg M.:"Plasma metallothionein antibody, urinary cadmium, and renal dysfunction in a Chinese type 2 diabetic population". Diabetes Care 2006 , 29:2682-87.

[231] Nunez M. :"Hepatotoxicity of antiretrovirals: Incidence,mechanisms and management". J Hepat. 2006, 44: 132-139

[232] O'Brien, C.B., D.S. Shields, S.H. Saul and R. Reddy. :"Drug induced vanishing bile duct syndrome: Response to ursodiol". Am. J. Gastroenterol.1996, 91: 1456-1457

[233] Odin JA, Huebert RC and Casciola-Rosen L. :"Bcl-2-dependant oxidation". J Clin Invest 2001, 108:223-32

[234] Ogawa M, Mori T, Mori Y, Ueda S, Azemoto R, Makino Y. et al. "Study on chronic renal injuries induced by carbon tetrachloride: selective inhibition of the nephrotoxicity by irradiation". Nephron 1992, 60:68-73.

[235] Ogeturk M, Kus I, Colakoglu N, Zararsiz I, Ilhan N and Sarsilmaz M: :"Caffeic acid phenethyl ester protects kidneys against carbon tetrachloride toxicity in rats". J.Ethnopharmacol. 2005, 97:273-280.

[236] Ohkawa,H.,Ohishi W and Yagi K .:" Assay for lipid peroxides in animal tissues by thiobarbituric acidreaction"..Biochem. $1979,95,351$

[237] Olagunjua JA, Adeneyeb AA ,Fagbohunkac BS ,Bisugac NA ,Ketikuc AO and Benebod AS . "Nephroprotective activities of the aqueous seed extract of Carica papaya Linn. in carbon tetrachloride induced renal injured Wistar rats: a dose- and time-dependent study".Biology and Medicine.2009., Vol. 1 (1): 11-19

[238] Olyaei AJ, de Mattos AM and Bennett WM. :"Immunosuppressant-induced nephropathy: pathophysiology, incidence and management". Drug Saf.1999,21(6):471-488.

[239] Ooghe, W. C., and Detavernier, C. M. :" .Detection of the addition of citrus reticulata and hybrids to citrus sinensis by flavonoids" J.Agric. Food Chem. 1997 , 45:1633-1637.

[240] Ostapowicz G., Fontana R.J., Schiodt F.V., Larson A., Davron J.T., Steven H.B., Timothy M. and Reish J. "Results of a prospective study of acute liver failure at 17 tertiary care centers in the United States". Ann Intern Med 2002,137: 947954.

[241] Ozbek E., Ilbey Y. O., Ozbek M., Simsek A., Cekmen M.and Somay A.: "Melatonin attenuates unilateral ureteral obstruction-induced renal injury by reducing oxidative stress, iNOS, MAPK, and NF-kB expression" .Journal of Endourology 2009, 23: 1165-1173.

[242] Ozbek E., Ilbey Y. O., Simsek A., Cekmen M., Mete F., and Somay, A.:"Rosiglitazone, peroxisome proliferator receptor gamma agonist, ameliorates gentamicin-induced nephrotoxicity in rats”. International Urology and Nephrology, 2010, 42: 579-587.

[243] Padma V.V., Suja V. and Shyamala D.C.S. :"Hepatoprotective effect of Liv-52 on antitubercular drug-induced hepatotoxicity in rats". Fitoterapia 1998, 69(6): 520-522

[244] Palmer BF. :"Renal dysfunction complicating the treatment of hypertension".N Engl J Med. 2002 , 347(16):1256-1261.

[245] Pari, L. and Kumar, N.A.,:"Hepatoprotective activity of Moringa oleifera on antitubercular drug-induced liver damage in rats". J. Med. Food. 2002, 5 (3), 171-177.

[246] Park S. H. , Pradeep K. , Ko K. C. , Choi M. H. , Kang J. A. and Chung Y. J. :"Hesperidin and Curdlan treatment ameliorates $\gamma$-radiation induced cellular damage and oxidative stress in the liver of Sprague-Dawley rats".Journal of Medicinal Food 03/2012; 15(5):419-27

[247] Pastore, A., Federici, G., Bertini, E., and Piemonte, F. :"Analysis of glutathione:Implication in redox and detoxification". Clin. Chim. Acta. 2003, 333: 19-39.

[248] Perazella MA. :"Crystal-induced acute renal failure". Am J Med. 1999 , 106(4):459-465.

[249] Perazella MA. :"Drug-induced nephropathy: an update". Expert Opin Drug Saf. 2005 , 4(4):689-706. 
[250] Perazella MA. :"Drug-induced renal failure: update on new medications and unique mechanisms of nephrotoxicity". Am J Med Sci. 2003 , 325(6):349-362.

[251] Perche O, Vergnaud-Gauduchon J, Morand C, Dubray C, Mazur A and Vasson MP. :" Orange juice and its major polyphenol hesperidin consumption do not induce immunomodulation in healthy well-nourished humans". Clin Nutr. pii: 2013 , (13)S0261-S614.

[252] Pereira-Filho G, Ferreira C, Schwengber A, Marroni C, Zettler C and Marroni N. :"Role of N-acetylcysteine on fibrosis and oxidative stress in cirrhotic rats".Arq Gastroenterol. $2008,45(2): 156-62$.

[253] Peterson J J, Dwyer J T, Beecher G R, Bhagwat S A,. Gebhardt S E, Haytowitz D B, et al. :"HoldenFlavanones in oranges, tangerines (mandarins), tangors, and tangelos: a compilation and review of the data from the analytical literature" Journal of Food Composition and Analysis 2006, 19: S66-S73 .

[254] Petkau, A., Chelack, W., Pleskach, S., Meeker, B., and Brady, C.: :"Radioprotection of Mice by Superoxide Dismutase".Biochem Biophys Res Commun.1975, 65:p886

[255] Pham PT, Peng A and Wilkinson AH, :"Cyclosporine and tacrolimus associated thrombotic microangiopathy". Am J Kidney Dis. 2000 , 36:844-850.

[256] Pham T-V, Lu S and Kaplowitz N. :"Acetaminophen hepatotoxicity". In: Taylor MB, ed. Gastrointestinal emergencies. 2nd ed. Baltimore: Williams \& Wilkins 1997 p371-88.

[257] Pisoni R, Ruggenenti P and Remuzzi G. :"Drug-induced thrombotic microangiopathy: incidence, prevention and management". Drug Saf. 2001 , 24(7):491-501.

[258] Pizzorno Jr and MurrayMT, 1999 Textbook Of Natural Medicine. Churchil Livingstone:Edinbourgh;79.

[259] Pradeep K, Park SH and Ko KC. :"Hesperidin a flavanoglycone protects against gamma-irradiation induced hepatocellular damage and oxidative stress in Sprague-Dawley rats"..Eur J Pharmacol. 2008 Jun 10;587(1-3):273-80.

[260] Prakash T., Fadadu S. D., Sharma U. R., Surendra V., Goli D.,et al "Hepatoprotective activity of leaves of Rhododendron arboreum in CCl4 induced hepatotoxicity in rats" Journal of Medicinal Plants Research .2008 , 2 (11): 315-320.

[261] Prendergast BD and George CF. :"Drug-induced rhabdomyolysis mechanisms and management". Postgrad Med J. 1993, 69(811):333-336.

[262] Price KL, Sautin YY, Long DA, Zhang L, Miyazaki H, Mu W, Endou H, Johnson RJ "Human vascular smooth muscle cells express a urate transporter". J. Am. Soc. Nephrol 2006 ,17 (7): 1791-5

[263] Prozialeck WC, Vaidya VS, Liu J, Waalkes MP, Edwards JR, Lamar PC, et al. :"Kidney injury molecule-1 is an early biomarker of cadmium nephrotoxicity". Kidney Int 2007, 72:985-93.

[264] Pryor, W. A., and Squadrito, G. L. :"The chemistry of peroxynitrite: A product from the reaction of nitric oxide with superoxide". Am. J. Physiol. 1995, 268: L699-L722

[265] Pushpakiran G, Mahalakshmi K, Anuradha CV Protective effects of taurine on glutathione and glutathione-dependent enzymes in ethanol-fed rats. Pharmazie.2004,59(11): 869-872

[266] Quintieri L, Palatini P, Moro S and Floreani M. " Inhibition of cytochrome PHYPERLINK "http://www.ncbi.nlm.nih.gov/pubmed/21791871"450 "http://www.ncbi.nlm.nih.gov/pubmed/21791871"CHYPERLINK "http://www.ncbi.nlm.nih.gov/pubmed/21791871"8HYPERLINK～"http://www.ncbi.nlm.nih.gov/pubmed/21791871"mediated drug metabolism by the HYPERLINK "http://www.ncbi.nlm.nih.gov/pubmed/21791871"flavonoid diosmetin". Drug Metab Pharmacokinet. 2011, 26(6):559-68 .

[267] Raghavendra, Mallikarjun and Vidya M.J:"Functions of kidney \& artificial kidneys" International Journal Of Innovative Research In Electrical, Electronics, Instrunentations And Control Eengineering 2013 , Vol. 1, Issue 1

[268] Rajesh M G and Latha M S. : "Protective activity of Glycyrrhiza glabra Linn. on carbon tetrachloride-induced peroxidative damage: “. Indian J Pharmacol. 2004,36:284-7

[269] Recknagel R.O., Glendek E.A.Jr., Dolakk J.A. and Waller R.L. :"Mechanisms of carbon tetrachloride toxicity Pharmacol". Ther. 1989, 43:139-154

[270] Reichle F.M. and Conzen P.F. :" Halogenated inhalational anesthetics".Best Practice \& Research Clin Anaesthesiol.2003, 17: 29-46.

[271] Reimund E. and Ramos A.: "Niacin-induced hepatitis and thrombocytopenia after 10 years of niacin use ". J Clin Gastroenterol. 1994,18: 270-271

[272] Reynolds ES,Trienen RJ,Farrish HH and Moslen MT "Relationship between the pharmacokinetics of Carbon tetrachloride conversion to Carbon dioxide and chloroform and liver injury" Arch,Toxicol. 1984 ,7(supple.):303-306.

[273] Rhoden EL, Pereira-Lima L, Kalil AN, Lucas ML, Mauri M, Menti E, et al. :"Effects of ischemia and reperfusion on oxidative stress in hepatic cirrhosis induced by carbon tetrachloride in rats". Kobe J Med Sci. 2000 Aug;46(4):171-80.

[274] Richter C., Gogvadze V. and Laffranchi R. : "Oxidants in mitochondria: from physiology to diseases". Biochimica et Biophysica Acta 1995 , 1271: 67-74. 
[275] Rizza S, Muniyappa R, Iantorno M, Kim JA, Chen H, Pullikotil P, et al. :"Citrus polyphenol hesperidin stimulates production of nitric oxide in endothelial cells while improving endothelial function and reducing inflammatory markers in patients with metabolic syndrome". J Clin Endocrinol Metab. 2011 , 96(5):E782-92.

[276] Roberts, D. W., Bucci, T. J., Benson, R. W., Warbritton, A. R., McRae, T. A.,Pumford, N. R., and Hinson, J. A.:"Immunohistochemical localization and quantification of the 3-(cystein-S-yl)-acetaminophen protein adduct in acetaminophen hepatotoxicity". Am. J. Pathol. 1991, 138, 359-371.

[277] Robin MA, Le Roy M and Descatoire V. :" Plasma membrane cytochromeP450 as neoantigens and autoimmune targets in drug-induced hepatitis". J Hepatol 1997, 26(Suppl 1):23-30.

[278] Rocchi, P; Prodi and G; Grilli, S. :"In vivo and in vitro binding of carbon tetrachloride with nucleic acids and proteins in rats and mouse liver". Int J Cancer 1973, 11:419-425

[279] Rodman J.S., Deutsch D.J. and Gutman S.I. :"Methyl dopa hepatitis. A report of six cases and a review of the literature". Am J Med. 1976, 60:941-948

[280] Rossert J. :"Drug-induced acute interstitial nephritis". Kidney Int. 2001 , 60(2):804-817

[281] Rudnicki MA, Schnegelsberg PN, Stead RH, Braun T, Arnold HH and Jaenisch R. :"MyoD or Myf-HYPERLINK "http://www.ncbi.nlm.nih.gov/pubmed/8269513"5 HYPERLINK "http://www.ncbi.nlm.nih.gov/pubmed/8269513"is required for the formation of skeletal muscle". Cell. 1993, 75(7):1351-9.

[282] Rudnicki, M., Silveira, M. M., Pereira, T.V., Oliveira, M. R.; Reginatto, F. H.et al. :"Protective effects of Passiflora alata extract pretreatment on carbon tetrachloride induced oxidative damage in rats". Food Chem. Toxicol. 2007:, 45: 656-661.

[283] Ruprah H., Mant T. G. K and Flanagan R. J. .: "Acute carbon tetrachloride poisoning in 19 patients:implications for diagnosis and treatment". Lancet.1985, 1: 1027-1029.

[284] Russo J, Hasan Lareef M, Balogh G, Guo S and Russo IH. :"Estrogen and its metabolites are carcinogenic agents in human breast epithelial cells". J Steroid Biochem Mol Biol. 2003, 87(1):1-25 .

[285] Ryter, E., Kim H., Hoetzel A., Park J., Nakahira K., Wang X. et al. :"Mechanisms of cell death in oxidative stress" . Antioxid. Redox Signal 2007,(9): 49-89.

[286] Sahreen S, Siddiq P,Shah N.A, Khan M.R and Khan R.A :"Modulation of carbon tetrachloride-induced nephrotoxicity in rats by n-hexane extract of Sonchus asper " Toxicol Ind Health 2013 P80-94 doi: 10.1177/0748233713485885

[287] Sahu BD, Kuncha M, Sindhura GJ and Sistla R :" Hesperidin attenuates cisplatin-induced acute renal injury by decreasing HYPERLINK "http://www.ncbi.nlm.nih.gov/pubmed/23353054"oxidative stress, inflammation and DNA damage". Phytomedicine. 2013, 20(5):453-60.

[288] Sakurai, K., and Cederbaum, A. I. :" Oxidative stress and cytotoxicity induced by ferric-nitrilotriacetate in HepG2 cells expressing CYP 2E1". Mol.Pharmacol. 1998 , 54: 1024-1035

[289] Samouilidou EC and Grapsa EJ :"Oxidative stress markers and C-reactive protein in end-stage renal failure patients on dialysis". Int Urol Nephrol .2003, 35 (3): 393-7.

[290] Satoh K, :" Serum lipid peroxide in cerebrovascular disorders determined by a new colorimetric method".Clinical Chemical Acta (1978),90,37.

[291] Sato N, Seiwa C, Uruse M, Yamamoto M, Tanaka K, Kawakita T, et al. :" Administration of chinpi, a component of the herbal medicine ninjin-youei-to, reverses age-induced demyelination". Evid Based Complement Alternat Med. 2011, Article ID 617438.

[292] Scarborough H. :"Deficiency of Vitamin C and Vitamin P in Man" The Lancet. 1940, -\%\%X- HYPERLINK "7\%22\%20236:"236HYPERLINK "7\%22\%20236:": 644 - 647.

[293] Schetz M, Dasta J, Goldstein S and Golper T. :"Drug-induced acute kidney injury". Curr Opin Crit Care. 2005 , 11(6):555565.

[294] Schmitz G, Kaminski WE, Porsch-Ozcürümez M, Klucken J, Orsó E, Bodzioch M, et al. :"ATP-binding cassette transporter AHYPERLINK "http://www.ncbi.nlm.nih.gov/pubmed/10725792"1 HYPERLINK "http://www.ncbi.nlm.nih.gov/pubmed/10725792"(ABCAHYPERLINK

"http://www.ncbi.nlm.nih.gov/pubmed/10725792"1HYPERLINK "http://www.ncbi.nlm.nih.gov/pubmed/10725792") in macrophages: a dual function in inflammation and lipid metabolism". Pathobiology. 1999, 67(5-6):236-40.

[295] Schnellmann RG and Kelly KJ. :"Pathophysiology of nephrotoxic acute renal failure" . In: Berl T, Bonventre JV, eds. Acute Renal Failure. Philadel phia, Pa.: Blackwell Science 1999, Schrier RW, ed. Atlas of Diseases of the Kidney,vol1.1http://www.kidneyatlas.org/bookHYPERLINK

"/\%20adk115.\%20pdf\%22http://www.kidneyatlas.org/book1/\%20adk115.\%20pdf"1HYPERLINK

"/\%20adk115.\%20pdf\%22http://www.kidneyatlas.org/book1/\%20adk115.\%20pdf"/

"/\%20adk1 15.\%20pdf\%22http://www.kidneyatlas.org/book1/\%20adk115.\%20pdf"115HYPERLINK

adkHYPERLINK

"/\%20adk115.\%20pdf\%22http://www.kidneyatlas.org/book1/\%20adk115.\%20pdf". pdf. Accessed November 8, 2007 
[296] Schoolwerth AC, Sica DA, Ballermann BJ and Wilcox CS. :"Renal considerations in angiotensin converting enzyme inhibitor therapy": a statement for healthcare professionals from the Council on the Kidney in Cardiovascular Disease and the Council for High Blood Pressure Research of the American Heart Association. Circulation. 2001, 104(16):1985-1991.

[297] Seiwa C, Yamamoto M, Tanaka K, Fukutake M, Ueki T, Takeda S, et al.:"Restoration of FcRgamma/Fyn signaling repairs central nervous system demyelination". J Neurosci Res. 2007 , 85(5):954-66.

[298] Selim K. and Kaplowitz N. :"Hepatotoxicity of Psychotropic Drugs". Hepatology. 2003, 29: 1348-1350.

[299] Selvaraj P and Pugalendi KV. :" Efficacy of hesperidin on plasma, heart and liver tissue lipids in rats subjected to isoproterenol-induced cardiotoxicity". Exp Toxicol Pathol. 2012, 64(5):449-52.

[300] Seo BM, Miura M, Gronthos S, Bartold PM, Batouli S, Brahim J, et al. :" Investigation of multipotent postnatal stem cells from human periodontal ligament". Lancet. 2004, 364(9429):149-55.

[301] Sesink AL, Aloys L. A. Sesink, Ilja C. W. Arts,Maria Faassen-Peters, and Peter C.H. Hollman. :"Intestinal uptake of quercetin-HYPERLINK

"http://www.ncbi.nlm.nih.gov/pubmed/12612151"3HYPERLINK "http://www.ncbi.nlm.nih.gov/pubmed/12612151"-glucoside in rats involves hydrolysis by lactase phlorizin hydrolase". J. Nutr. 2003 , 133 :773-776.

[302] Shahid M, Dumat C, Silvestre J and Pinelli:"Effect of fulvic acids on lead-induced oxidative stress to metal sensitive Vicia faba L. plant." Biol Fert Soils. 2012c, 10.1007/s00374-012-0662-9

[303] Shankar M, Gowrishankar.N. L, David Raj C., Ansar MD., Pranathi P.and Raju G. :"Screening of Methanolic Extract of Eugenia Jambolana Leaves for its Hepatoprotective Activity in Carbon Tetrachloride Induced Rats" International Journal of Applied Research in Natural Products 2012, 5 (2):14-18.

[304] Shear N and Spielberg S. :"Anticonvulsant hypersensitivity syndrome: invitro assessment of risk". J Clin Invest 1988, $82: 1826-32$.

[305] Shirasaka Y, Shichiri M, Mori T, Nakanishi T and Tamai I. :" Major active components in grapefruit, orange, and apple juices responsible for OATPHYPERLINK "http://www.ncbi.nlm.nih.gov/pubmed/23794501"2HYPERLINK "http://www.ncbi.nlm.nih.gov/pubmed/23794501"BHYPERLINK "http://www.ncbi.nlm.nih.gov/pubmed/23794501"1HYPERLINK～"http://www.ncbi.nlm.nih.gov/pubmed/23794501"mediated drug interactions". J Pharm Sci. 2013, 102(9):3418-26.

[306] Shrivastava M, Kar V and Shrivastava S :"Cyclophosphamide altered the myocardial marker enzymes: protection provoked by hesperidin in rats". J App Pharm . 2011, 4(03): 407-415 .

[307] Schumann G, Bonora R, Ceriotti F, Férard G et al. :" IFCC primary reference procedure for the measurement of catalytic activity concentrations of enzymes at $37^{\circ} \mathrm{C}$. Part 5 : Reference procedure for the measurement of catalytic concentration of aspartate aminotransferase".. Clin Chem Lab Med 2002;40:725-33.

[308] Singh, C., P. Bishop and R. Wilson. :"Extreme hyperbilirubinemia associated with the use of anabolic steroids, health/nutritional supplements and ethanol: Response to ursodeoxycholic acid treatment". Am. J. Gastroenterol. 1996, 91: 783-785.

[309] Siu-Po I and Kam-Ming K:" The crucial antioxidant action of schisandrin B in protecting against carbon tetrachloride hepatotoxicity in mice: A comparative study with butylated hydroxytoluene" Biochem Pharmacol. 1996 ,13;52(11):168793.

[310] Smythe M.A. and Umstead J.S. :"Phenytoin hepatotoxicity: a review of the literature". Ann Pharmacotherapy. 1989, 23: 13-18.

[311] Souza LC, de Gomes MG, Goes AT, Del Fabbro L, Filho CB, Boeira SP, et al.:" Evidence for the involvement of the serotonergic HYPERLINK "http://www.ncbi.nlm.nih.gov/pubmed/22996046"-HT(HYPERLINK

"http://www.ncbi.nlm.nih.gov/pubmed/22996046"1HYPERLINK＂ "http://www.ncbi.nlm.nih.gov/pubmed/22996046"A) receptors in the antidepressant-like effect caused by hesperidin in mice". Prog Neuropsychopharmacol Biol Psychiatry. 2013 , 40:103-9.

[312] Stephen O. A., Salako A.A., Doherty O. W. and Naicker T. :"Effect of Melatonin on Carbon Tetrachloride- Induced Kidney Injury in Wistar Rats" African Journal of Biomedical Research, Vol. 10 (2007); 153 - 164.

[313] St-Pierre J, Drori S, Uldry M, Silvaggi JM, Rhee J, Jäger S, et al :"Suppression of reactive oxygen species and neurodegeneration by the PGC-HYPERLINK "http://www.ncbi.nlm.nih.gov/pubmed/17055439"1 HYPERLINK "http://www.ncbi.nlm.nih.gov/pubmed/17055439"transcriptional coactivators". Cell. 2006 , 127(2):397-408.

[314] Stryjecka-Zimmer M, Szymonik-Lesiuk S, Czechowska G, Słomka M, Madro A and Celiński K, :"Catalase, superoxide dismutase, and glutathione peroxidase activities in various rat tissues after carbon tetrachloride intoxication. " Journal of Hepato-Biliary-Pancreatic Surgery 2003; 10(4):309-15

[315] Sulkowski M., Thomas D., Chaisson R. and Moore R. : "Hepatotoxicity associated with antiretroviral therapy in adults infected with HIV and the role of hepatitis C or B virus infection". J Am Med Assoc. 2000, 283: 74-80. 
[316] Szymonik-Lesiuk, S., Czechowska, G., Stryjecka-Zimmer, M., Slomka, M., Madro, A., Celinski, K.et al :"Catalase, superoxide dismutase, and glutathione peroxidase activities in various rat tissues after carbon tetrachloride intoxication". J. Hepatobiliary Pancreat. Surg. 2003b, 10: 309-315

[317] Takeda H, Sadakane C, Hattori T, Katsurada T, Ohkawara T, Nagai K, et al.:"Rikkunshito, an herbal medicine, suppresses cisplatin-induced anorexia in rats via HYPERLINK "http://www.ncbi.nlm.nih.gov/pubmed/18439428"5HYPERLINK "http://www.ncbi.nlm.nih.gov/pubmed/18439428"-HTHYPERLINK "http://www.ncbi.nlm.nih.gov/pubmed/18439428"2 HYPERLINK "http://www.ncbi.nlm.nih.gov/pubmed/18439428"receptor antagonism". Gastroenterology. 2008, 134(7):2004-13.

[318] Takumi H, Nakamura H, Simizu T, Harada R, Kometani T, Nadamoto T, et al :" Bioavailability of orally administered water-dispersible hesperetin and its effect on peripheral vasodilatation in human subjects: implication of endothelial HYPERLINK "http://www.ncbi.nlm.nih.gov/pubmed/22307524"functions of plasma conjugated metabolites. " Food Funct. 2012 , 3(4):389-98.

[319] Tamai I. :"Oral drug delivery utilizing intestinal OATP transporters". Adv Drug Deliv Rev. 2012 ,64(6):508-14.

[320] Tanaka T, Makita H, Kawabata K, Mori H, Kakumoto M, Satoh K, et al:" Chemoprevention of azoxymethane-induced rat colon carcinogenesis by the naturally occurring flavonoids, diosmin and hesperidin". Carcinogenesis. 1997, 18(5):957-65.

[321] Tarazi EM, Harter JG and Zimmerman H, :"Sulindac-associated hepatic injury: analysis of 91 cases reported to the Food and Drug Administration".Gastroenterology 1993, 104:569-74.

[322] Taylor PC. :"Anti-tumor necrosis factor therapies". Curr Opin Rheumatol. 2001, 13(3):164-9.

[323] The World Book Encyclopedia. Volume 3. 1992. Chicago: World Book Inc. 1992, pp. 366-7.

[324] Thomas L., :"Alanine aminotransferase (ALT), A spartate aminotransferase (AST) ". In: Thomas L., editor. Clinical Laboratory Diagnostic. 1st ed .Frankfurt: TH-Books veriagsgesellschaft(1998).p.55-65.

[325] Thompson N, Caplin M and Hamilton M,:"Anti-tuberculosis medication and the liver: dangers and recommendations in management". Eur Respir J 1995, 8:1384-8

[326] Tietz, N. W., ed., "Clinical Guide to Laboratory Tests”, 2nd Edition, W.B. Saunders Company, Philadelphia (1994)

[327] Tilg H and Hotamisligil GS :"Nonalcoholic fatty liver disease: Cytokine-adipokine interplay and regulation of insulin resistance". Gastroenterology.2006,131: 934-945.

[328] Tirkey N, Pilkhwal S, Kuhad A and Chopra K :"Hesperidin, a citrus bioflavonoid, decreases the oxidative stress produced by carbon tetrachloride in rat liver and kidney". BMC Pharmacology 2005, 5:2

[329] Tom WM, Fong D, Woo B, Prasongwatana V and Boyde TR,:"Microsomal lipid peroxidationand oxidative metabolism in rat liver". Chemical and Biological Interactions 1984, 50: 361 - 363.

[330] Tostmann A., Boeree M.J., Aarnoutse R.E., Lange W.C.M.,Vander Ven A.J. and Dekhuijzen R. :"Anti-tuberculosis druginduced hepatotoxicity": Concise up-to-date review. J Gastroenterol Hepatol . 2008 ,23: 192-202.

[331] Tripoli E, Guardia M, Giammanco S, Di Majo D and Giammanco M. :"Citrus flavonoids: Molecular structure, biological activity and nutritional properties: A review". Food Chemistry .2007; 104: 466-479.

[332] Tsukahara-Ohsumi Y, Tsuji F, Niwa M, Hata T, Narita M, Suzuki T, et al :"The kappa opioid receptor agonist SAHYPERLINK "http://www.ncbi.nlm.nih.gov/pubmed/21970808"14867 HYPERLINK "http://www.ncbi.nlm.nih.gov/pubmed/21970808"has antinociceptive and weak sedative effects in models of acute and chronic pain". Eur J Pharmacol. 2011 , 671(1-3):53-60.

[333] Tucker P. :"Case studies in environmental medicine: cadmium toxicity" Agency for Toxic Substances and Disease Registry (ATSDR). 2008 , p10-44. Available at: www.atsdr.cdc.gov/csem/cadmium/ [Accesses: june 25, 2010]

[334] Tugcu V., Ozbek E. and Tasci.A. I.:"Selective nuclear factor kappa-B inhibitors, pyrolidium dithiocarbamate and sulfasalazine, prevent the nephrotoxicity induced by gentamicin”. British Journal of Urology International 2006, 98 : 680-686.

[335] Uetrecht J. :"New concepts in immunology relevant to idiosyncratic drug reactions: the "danger" hypothesis and innate immune system". ChemRes Toxicol 1999, 12:387-95.

[336] Valko M, Leibfritz D, Moncola J, Cronin M, Mazura M and Telser I. :"Free radicals and antioxidants in normal physiological functions and human disease". Int J Biochem Cell Biol. 2007, 39(1):44-84.

[337] Vitaglione P, Morisco F, Caporaso N and Fogliano V :"Dietary antioxidant compounds and liver health". Crit Rev Food Sci Nutr . $2004,44: 575-586$.

[338] Von Oettingen and W.F. :"The Halogenated, Aliphatic, Olefinic, Cyclic Aromatic, and Alipatic-aromatic hydrocarbons Including the Halogenated Insecticides." U.S. Public Health Service Publ. 1959, 414:15-30.

[339] Vulimiri, S.V., Berger, A.and Sonawane, B. "The potential of metabolomic approaches for investigating mode(s) of action of xenobiotics. Case study with carbon tetrachloride". Mutat. Res.2011, 722, 147-153.

[340] Wahsha M and Al-Jassabi S. :"The role of Silymarin in the protection of mice liver damage against Microcystin-LR toxicity". Jordan Journal of Biological Sciences, 2009; 2 (2): 63-68. 
[341] Walker A.M. :"Quantitative studies of the risk of serious hepatic injury in persons using nonsteroidal anti-inflammatory drugs". Arthritis Rheum 1997, 40: 201-208

[342] Walker U., Setzer B. and Venhoff N. :" Increased long-term mitochondrial toxicity in combinations of nucleoside analogue reversetranscriptase inhibitors". AIDS. 2002, 16: 2165-2173.

[343] Wang J, Xu X, Elliott MH, Zhu M and Le YZ. :"Müller cell-derived VEGF is essential for diabetes-induced retinal inflammation and vascular leakage". Diabetes. 2010 ,59(9):2297-305.

[344] Wang L, Wang H, Hu M, Cao J, Chen D and Liu Z. :"Oxidative stress and apoptotic changes in primary cultures of rat proximal tubular cells exposed to lead". Arch Toxicol 2009, 83:417-27.

[345] Wang X, Sakurai T and Chen X. :"Hydrolysis of flavanone glycosides and degradation of the corresponding aglycones from dried immature Citrus fruit by human fecal flora in vitro". Planta Med. 2008, 74(14) :1751-5.

[346] Wang YQ, Zhang HM, Zhang GC and Tao WH :"Interaction of the flavonoid hesperidin with bovine serum albumin: A fluorescence quenching study" Journal of Luminescence . 2007, 126: 211-218.

[347] Wasowski C, Loscalzo LM, Higgs J and Marder M. :"Chronic intraperitoneal and oral treatments with hesperidin induce HYPERLINK "http://www.ncbi.nlm.nih.gov/pubmed/21717517"central nervous system effects in mice". Phytother Res. $2012,26(2): 308-12$.

[348] Weber LW, Boll M and Stampfl A. :"Hepatotoxicity and mechanism of action of haloalkanes: carbon tetrachloride as a toxicological model". Crit Rev Toxicol. 2003,33:105-36

[349] Wei D, Ci X, Chu X, Wei M, Hua S and Deng X. :"Hesperidin suppresses ovalbumin-induced airway inflammation in a mouse allergic asthma model". Inflammation. 2012, 35(1):114-21 .

[350] Wei L.and Jun L. :"Protective Effects and Mechanisms of Hesperidin Against Acute Chemical Liver Injuries in Mice". China Papers June 29, $2010 \quad$ http://mt.china-papers.com/HYPERLINK "http://mt.chinapapers.com/2/?p=50550"2HYPERLINK "http://mt.china-papers.com/2/?p=50550"/?p=HYPERLINK "http://mt.chinapapers.com/2/?p=50550"50550

[351] Wellman PJ, Clifford PS and Rodriguez JA. "Ghrelin and ghrelin receptor modulation of psychostimulant action". Front Neurosci. 2013,p 7:171.

[352] Williamson G and Manach C. "Bioavailability and bioefficacy of polyphenols in humans. II. Review of HYPERLINK "http://www.ncbi.nlm.nih.gov/pubmed/15640487"93 "http://www.ncbi.nlm.nih.gov/pubmed/15640487"intervention studies". Am J Clin Nutr. 2005 , 81 : 243S-255S .

[353] Willis D., Moore A.R., Frederick R. and Willoughby D.A. "Heme oxygenase: a novel target for the modulation of the inflammatory response". Nat Med. 1996, 2: 87 - 93.

[354] Wit F., Weverling G., Weel J., Jurrians S. and Lange J.:"Incidence and risk factors for severe hepatotoxicity associated with antiretroviralcombination therapy". J Infect Dis. 2002, 186: 23-31.

[355] Wu, D., and Cederbaum, A. I. :"Ethanol-induced apoptosis to HepG2 cell lines expressing human cytochrome P4502E1. Alcohol". Clin. Exp. Res. 1999, 23: 67-76.

[356] Xiao-min Y ,Jun-ge Q, Qing-zhi L,Hong-wei L, Guo-kang W and Quan-yi X.:"Comparative Effects of Baicalin and Hesperidin on Hepatotoxicity Induced by Cisplatin in Mice ".Journal of Liaoning University of Traditional Chinese Medicine . 2011-06

[357] Yachi R, OsamuI , garashi O and Kiyose C, :" Protective effect of vitamin E against carbon tetrachloride induced fatty liver in rats"J. Clin. Biochem. Nutr. 2010, (47): 148-154

[358] Yakabi K, Kurosawa S, Tamai M, Yuzurihara M, Nahata M, Ohno S, et al :"Rikkunshito and HYPERLINK "http://www.ncbi.nlm.nih.gov/pubmed/20171995"5HYPERLINK～"http://www.ncbi.nlm.nih.gov/pubmed/20171995"HTHYPERLINK

"http://www.ncbi.nlm.nih.gov/pubmed/20171995"2HYPERLINK "http://www.ncbi.nlm.nih.gov/pubmed/20171995"C receptor antagonist improve cisplatin-induced anorexia via hypothalamic ghrelin interaction". Regul Pept. 2010, 161(1-3):97-105.

[359] Yamamoto M, Jokura H, Hashizume K, Ominami H, Shibuya Y, Suzuki A, et al. :" Hesperidin metabolite hesperetinHYPERLINK

"http://www.ncbi.nlm.nih.gov/pubmed/23831969"7HYPERLINK "http://www.ncbi.nlm.nih.gov/pubmed/23831969"-O-glucuronide, but not hesperetin-HYPERLINK "http://www.ncbi.nlm.nih.gov/pubmed/23831969"3HYPERLINK＂http://www.ncbi.nlm.nih.gov/pubmed/23831969"'-Oglucuronide, exerts hypotensive, vasodilatory, and anti-inflammatory activities". Food Funct. 2013, 4(9):1346-51.

[360] Yang YL, Hsu HT, Wang KH, Wang CS, Chen CM and Ko WC. . :"Hesperidin-HYPERLINK "http://www.ncbi.nlm.nih.gov/pubmed/23082087"3HYPERLINK＂ "http://www.ncbi.nlm.nih.gov/pubmed/23082087"'-omethylether is more potent than hesperidin in phosphodiesterase inhibition and suppression of HYPERLINK "http://www.ncbi.nlm.nih.gov/pubmed/23082087"ovalbumin-induced airway hyperresponsiveness". Evid Based Complement Alternat Med. 908562. (2012).

[361] Ye L, Chan FL, Chen S and Leung LK. :"The citrus flavonone hesperetin inhibits growth of aromatase-expressing MCFHYPERLINK $\quad$ "http://www.ncbi.nlm.nih.gov/pubmed/22209285"7

HYPERLINK 
American Research Journal of Pharmacy, Volume 1, Issue 2, 2015

"http://www.ncbi.nlm.nih.gov/pubmed/22209285"tumor in ovariectomized athymic mice". J Nutr Biochem. 2012, 23(10):1230-7.

[362] Yoshimura E, Fujii M and Koide S, :"A case of Chinese herbs nephropathy in which the progression of renal dysfunction was slowed by steroid therapy ". Jap J Nephrol 2000, 42:66-72.

[363] Yue L, Ye F, Gui C, Luo H, Cai J, Shen J, et al :"Ligand-binding regulation of LXR/RXR and LXR/PPAR heterodimerizations: SPR technology-based kinetic analysis correlated with molecular dynamics simulation". Protein Sci. 2005, 14(3):812-22.

[364] Zager RA. :"Pathogenetic mechanisms in nephrotoxic acute renal failure".Semin Nephrol. 1997, 17(1):3-14.

[365] Zhang W, Yuan J, Yang Y, Xu L, Wang Q, Zuo W, Fang X and Chen YG.. "Monomeric type I and type III transforming growth factor- $\beta$ receptors and their dimerization revealed by single-molecule imaging". Cell Res. 2010, 20(11):1216-23 .

[366] Zhao Y. L., Zhou G. D. and Yang H. B. :"Rhein protects against acetaminophen-induced hepatic and renal toxicity". Food and Chemical Toxicology 2011, 49:1705-1710,

[367] Zielińska M, Kostrzewa A, Ignatowicz E and Budzianowski J.:"The flavonoids, quercetin and isorhamnetin 3-Oacylglucosides diminish neutrophil oxidative metabolism and lipid peroxidation".. Acta Biochimica Polonica. 2001; 48(1):183-189.

[368] Zimmerman H. :"Drug-induced liver disease". In: Schiff E, Sorell M,Madding W, eds. Schiff's diseases of the liver. 8th ed. Philadelphia: Lippencourt Raven 1999, p 973-1064

[369] Zimmerman H. :"Hepatotoxicity: the adverse effects of drugs and other chemicals on the liver". 2nd ed. Philadelphia: Lippincott, Williams \&Wilkins 1999, p483-498

[370] Zimmerman HJ. :"Drug-induced liver disease". Drugs 1978, 16 (1): 25-45

[371] Zimmerman SW, Norback DH and Powers K:"Carbon tetrachloride nephrotoxicity in rats with reduced renal mass". Arch Pathol Lab Med 1983, 107:264-269. 